\title{
1. Debt in Asia: anatomy, evolution, and prospects
}

\author{
Juan Pablo Paladino and Juan J. Pradelli ${ }^{1}$
}

\section{INTRODUCTION}

This chapter presents an empirical overview of debt in Asia and analyzes recent trends and prospective sustainability, particularly in view of the coronavirus disease (COVID-19) pandemic and its aftermath. It focuses on three types of debt-public, private, and external liabilities - and the developing member economies of the Asian Development Bank (ADB), referred to as developing Asia. The availability of well-established debt databases compiled by international organizations and the institutional relevance of developing Asia for ADB explains why the chapter squarely gravitates toward these liabilities and economies.

In this chapter, public debt refers to financial liabilities of the general government, compiled following the Government Finance Statistics standards of the International Monetary Fund (IMF). Private debt includes financial obligations, particularly loans and debt securities due by households, nonfinancial corporations-both private firms and state-owned enterprises, and financial corporations. Private debt data are compiled from several sources-for example, local sources and Bank for International Settlements - which generally follow standards such as the United Nations National Accounts and the International Financial Statistics of the IMF. Finally, external debt covers financial obligations of public- and private-sector residents to nonresidents. While public and private debt are defined from the perspective of debtors assuming financial obligations (i.e., who owes), external debt is defined from the viewpoint of creditors holding financial claims (i.e., who owns). ${ }^{2}$

The chapter describes the current landscape of debt in developing Asia, focusing specifically on debt sustainability issues in the region. ${ }^{3}$ The group of Asian developing economies stands out among other regional blocs for its moderate level of public indebtedness - measured relative to gross domestic product (GDP) - although it has been on a rising trend since the aftermath of the global financial crisis in 2008, that is, even before the COVID-19 pandemic unfolded in early 2020. The external debt of Asian developing economies as a whole is also relatively low by global standards - a legacy of the policies adopted after the Asian financial crisis in 1997, which geared toward deleveraging, development of domestic government debt markets, and self-insurance via accumulation of international reserves. On the other hand, the level of private indebtedness of developing Asia, relative to GDP, is among the highest among economic blocs worldwide, and has been growing at a fast pace in the recent past even before the COVID-19 pandemic, mainly driven by the leveraging of nonfinancial corporations in the People's Republic of China (PRC). 
The chapter also analyzes the specific debt situation and prospects for the individual developing Asian economies. In fact, heterogeneity across these economies, in terms of level of development, economic size, production structure, government policies, and other salient features, makes it challenging to formulate empirical and analytical generalizations for all of them. Nevertheless, stylized facts and patterns are identifiable among subgroups of developing Asian economies concerning the level, structure, and trends of their respective debts.

The debt outlook for developing Asian economies recognizes the economic and fiscal impact of the COVID-19 pandemic, whose consequences are expected to continue over the medium term, while its definitive resolution is still a policy challenge at the time of this writing. Given the uncertainty of the path of economic recovery and the reversal of policy responses adopted to cope with the pandemic in 2020 , the chapter assesses the outlook for public debt over the medium term on the basis of illustrative debt-dynamic simulations.

Section 1 describes the anatomy and evolution of debt in developing Asia, highlighting recent trends and comparing the region with other major economic blocs worldwide. Section 2 analyzes the debt of individual developing Asian economies and assesses vulnerabilities related to solvency and liquidity. Section 3 focuses on the impact of the COVID-19 pandemic on fiscal and debt outcomes in 2020-2021, including the efforts undertaken to mitigate the economic effects triggered by the health crisis. Finally, section 4 explores medium-term prospects for debt of these economies, with emphasis on public and external indebtedness in the aftermath of the COVID-19 pandemic, under a few illustrative scenarios.

\section{DEVELOPING ASIA'S DEBT FROM A GLOBAL PERSPECTIVE}

Global indebtedness threatens to reach record high levels. For the world as a whole, public debt is approaching 100 percent of global GDP and the private debt nears \$200 trillion, according to the IMF World Economic Outlook (WEO) and Institute of International Finance Debt Database (IIFDD) data. ${ }^{4}$ Against this background, this section documents that by and large, developing Asia managed to maintain relatively safe levels of public and external debt, mainly due to strong economic growth, prudent fiscal policy, and cautious external public borrowing. However, a rising trend for public debt commenced in the aftermath of the global financial crisis and accelerated during the COVID-19 pandemic in 2020. Some economies, notably in South Asia, already exhibited high levels of public debt as early as in the mid-2000s. As far as private debt is concerned, soon after the global financial crisis a handful of these economies built up a heavy burden of nonfinancial corporate debt, which is now among the highest worldwide.

\subsection{Public Debt}

Currently, developing Asian economies contribute more to the global economy than what they add to the world's total public debt. In 2020, developing Asia accounted for about 18 percent of government liabilities worldwide, while it generated 29 percent of the global output, when using GDP in current dollars to measure a country's output valued at domestic prices. ${ }^{5}$ Public debt of developing Asia amounted to $\$ 14.6$ trillion in 2020, while the world's was $\$ 82.1$ trillion, of which two-thirds corresponded to the United States (US) (\$27.3 trillion), Japan (\$13.1 
trillion), and the euro area (\$13.2 trillion) (see Figure 1.1). Among the group of developing Asian economies, the three largest economies in terms of output and population accounted for almost 80 percent of government liabilities: the PRC (\$9.0 trillion), India (\$2.2 trillion), and Indonesia (\$0.4 trillion).

The level of public debt relative to the economic size of developing Asia appears moderate compared with other regions. In 2020, the public debt-to-GDP ratio of developing Asia stood at 60 percent, well below the ratios for the world as a whole (98 percent) or advanced economies (129 percent), and close to the average of emerging economies (59 percent) (see Figure 1.2). From a regional perspective, public debt is the highest in South Asia compared with other geographic groups defined by ADB, and this has been so for several years (see Figures 1.2 and 1.3). As discussed in the next section, Bhutan, Maldives, Sri Lanka, India, and Pakistan currently exhibit government liabilities well above 70 percent of GDP. ${ }^{6}$

Developing Asia managed to preserve a moderate level of public indebtedness throughout the last 15 years, until the COVID-19 pandemic unfolded in 2020 (see Figure 1.3). The public debt-to-GDP ratio of developing Asia was 39 percent back in 2005 and grew by 13 percentage points by 2019. This mild increase is in stark contrast with the jump of 30 percentage points in the public debt ratio of advanced economies during the same period, and closer to the 9-percentage-point variation of other emerging economies. Heterogeneity within developing Asia should not be overlooked. Public debt grew in East Asia (24 percentage points) and Central Asia (12 percentage points), whose debt ratios almost doubled between 2005 and 2019. In contrast, the debt ratios changed little in the Pacific (5 percentage points), Southeast Asia ( -2 percentage points), and South Asia ( -6 percentage points).

For the group of Asian developing economies as a whole, the overall stability of their government liabilities relative to GDP, at least until 2019, primarily relates to sustained, high rates of economic growth. The real GDP of developing Asia expanded at an average rate of 6.8 percent per year between 2005 and 2019, nearly five times the growth rate of 1.6 percent achieved by advanced economies, and twice the 3.2 percent growth achieved by other emerging economies. In addition, as a group, governments in developing Asia tended to run more prudent fiscal policies, and borrow less, in normal times. Developing Asia even adopted a less expansionary stance when coping with the global financial crisis in 2008, while advanced economies largely resorted to public debt for financing fiscal responses, corporate and bank bailouts, and other interventions. ${ }^{7}$ Thus, between 2007 and 2019, the general government fiscal deficit of developing Asia averaged 2.2 percent of GDP per year, about half the deficit of 4.1 percent of GDP run by advanced economies and similar to the 2.3 percent deficit in other emerging economies.

More recently, the dynamics of government indebtedness in developing Asia looks less reassuring. Two trends have built up vulnerabilities even before the COVID-19 pandemic. First, the real GDP growth of developing Asia, albeit still high for global standards, has significantly decelerated, falling from an average annual rate of 8 percent in 2007-2011 at the height of the global financial crisis, to 6.3 percent in 2012-2015, and further to 5.8 percent in 2016-2019 (see Table 1.1). Growth deceleration is actually a common pattern across all geographic groups, and rather visible in the PRC and India. ${ }^{8}$ Second, since the mid-2010s, the governments of Asian developing economies have run more expansionary fiscal policies than they were used to. Between 2016 and 2019, the general government fiscal deficit of developing Asia averaged 3.8 percent of GDP per year, more than doubling the deficit of 1.6 percent 
of GDP achieved from 2007 to 2015 (see Table 1.1). ${ }^{9}$ Deteriorating fiscal balances are also a common pattern across the geographic groups, with the sole exception of South Asia whose deficits have been high for regional standards and only marginally reduced in recent years. ${ }^{10}$

\subsection{Private Debt}

While developing Asian economies make a modest contribution to the world's total public debt, they account for nearly one-quarter of the global private debt. The private debt of these economies totaled $\$ 50.9$ trillion in 2020, equivalent to 26 percent of the world's ( $\$ 197.2$ trillion), similar to the US (\$52 trillion), and significantly higher than the euro area (\$38.6 trillion) and Japan ( $\$ 18$ trillion) (see Figure 1.1). Private debt is heavily concentrated in a small group of large economies: the PRC (\$38.3 trillion); the Republic of Korea (ROK) ( $\$ 4.8$ trillion); India (\$1.7 trillion); and Hong Kong, China (\$1.8 trillion); jointly, they account for more than 90 percent of the private debt of the developing Asia group. ${ }^{11}$

Private debt of developing Asia peaked at 231 percent of GDP in 2020, not far from the ratio of the world as a whole (253 percent) (see Figure 1.2). From a regional perspective, East Asia ranks first in terms of private indebtedness (see Figures 1.2 and 1.3). Excluding liabilities owed by financial corporations, which are typically highly leveraged entities, and considering only household and nonfinancial corporate debt, developing Asia accounts for an even higher share - nearly one-third of the global private debt. Actually, the household and nonfinancial corporate debts of developing Asia relative to GDP (185 percent) are among the highest worldwide - comparable to the indebtedness of Japan (187 percent) and the euro area (175 percent). As discussed in the next section, the highest private debt ratios correspond to either large economies such as the PRC (226 percent) and the ROK (211 percent), or regional financial centers such as Hong Kong, China (350 percent) and Singapore (197 percent) (see Figure 1.4).

Private liabilities in Asian developing economies are owed by firms to a large extent. Nonfinancial corporations rely particularly on debt financing compared with other regional blocs. Relative to the economic size of the group of developing Asian economies, the liabilities of these firms are also the highest in the world, amounting to 132 percent of GDP in 2020 (Chapter 7). ${ }^{12}$ On the other hand, developing Asia households are relatively less leveraged than in other regions, and their financial obligations stood at only 53 percent of GDP in 2020 (Chapter 8).

Private debt across developing Asia is not only elevated in the present, it was also built up rather rapidly until 2016. Firms, particularly PRC private and state-owned enterprises borrowing from banks, drove corporate indebtedness; and total private liabilities actually expanded much faster than GDP, which was itself growing at a high speed (Chapter 3). ${ }^{13}$ During 2007-2016, the private debt-to-GDP ratio of developing Asia jumped from 136 percent to 199 percent - an increase of 63 percentage points unmatched by any other regional bloc (see Figure 1.3). ${ }^{14}$ Nonfinancial corporations and households fully explained the rise of the private debt ratio, and contributed 47 percentage points and 16 percentage points, respectively (see Figure 1.4). In contrast, private debt from 2016 to 2019 has been stable worldwide as well as in the group of developing Asian economies. ${ }^{15}$

The level and dynamics of household and corporate indebtedness in the Asian developing economies also present vulnerabilities. First, the real GDP growth of developing Asia is 
decelerating, as indicated earlier, and thus the incomes of debtor firms and households may no longer expand as fast as they used to. Second, the private debt of developing Asia may have financed investment expenditures that are increasingly less efficient, including housing construction and the acquisition of machinery and equipment by relatively inefficient firms. In this regard, a decreasing level of investment efficiency in some Asian economies, crudely measured by the incremental capital-output ratio, may also reduce debtors' repayment capacity. As a group, developing Asian economies have maintained high investment-to-GDP ratios for world standards, with annual ratios in the range of 37 percent to 40 percent between 2007 and 2019 (see Table 1.1). However, their gains in output growth narrowed significantly, with the average annual incremental capital-output ratio rising from 4.6 in 2007-2011 to around 6 in $2012-2019 .{ }^{16}$

\subsection{External Debt}

Asian developing economies contribute more to the global output than to the world's external debt. The external debt of developing Asia amounted to just $\$ 8.2$ trillion in 2019-less than 10 percent of the world's (\$87.2 trillion) (see Figure 1.1). The PRC (\$2.1 trillion); Hong Kong, China ( $\$ 1.7$ trillion); and Singapore (\$1.6 trillion) account for two-thirds of the foreign liabilities of the developing Asia group. Notably, the high volume of foreign liabilities in Singapore and Hong Kong, China results from their role as regional financial centers.

Relative to GDP, the foreign liabilities of developing Asia are among the lowest worldwide (see Figure 1.2). As developing Asian economies are rather open to international trade, and a significant share of their domestic output is exported, the external debt relative to their exports is also low by global standards. Excluding the regional financial centers, external debt is particularly salient in Central Asia, and protractedly so (see Figures 1.2 and 1.3), with a significant share owed by private-sector financial and nonfinancial corporations. ${ }^{17}$ As discussed in the next section, foreign liabilities exceed 70 percent of GDP in Mongolia, Bhutan, the Kyrgyz Republic, Georgia, Armenia, the Lao People's Democratic Republic (Lao PDR), Kazakhstan, Papua New Guinea, Tajikistan, Sri Lanka, and Maldives.

Notably, the external debt ratio of Asian developing economies as a group has been fairly low and stable for at least the last 15 years (see Figure 1.3). Developing Asia emerged from the Asian financial crisis in 1997 with a more prudent approach to foreign borrowing - both public and private - which resulted in significant deleveraging (Chapter 7). For a group of large developing Asian economies for which data are available, the governments reduced the share of external liabilities in total public debt from 45 percent in 1995 to 10 percent by 2008, and further to about 5 percent in the present. The mirror image of reduced borrowing abroad in foreign currency was an increased domestic financing in local currency, supported by efforts to develop markets for public debt (Chapter 14). ${ }^{18}$ In addition, the governments sought to build up international reserves to provide self-insurance against external shocks and capital-flow volatility. For the same group of major developing Asian economies, the international reserves rose from 10 percent of GDP in 1995 to 40 percent by 2008, and declined to around 20 percent currently. ${ }^{19}$ 

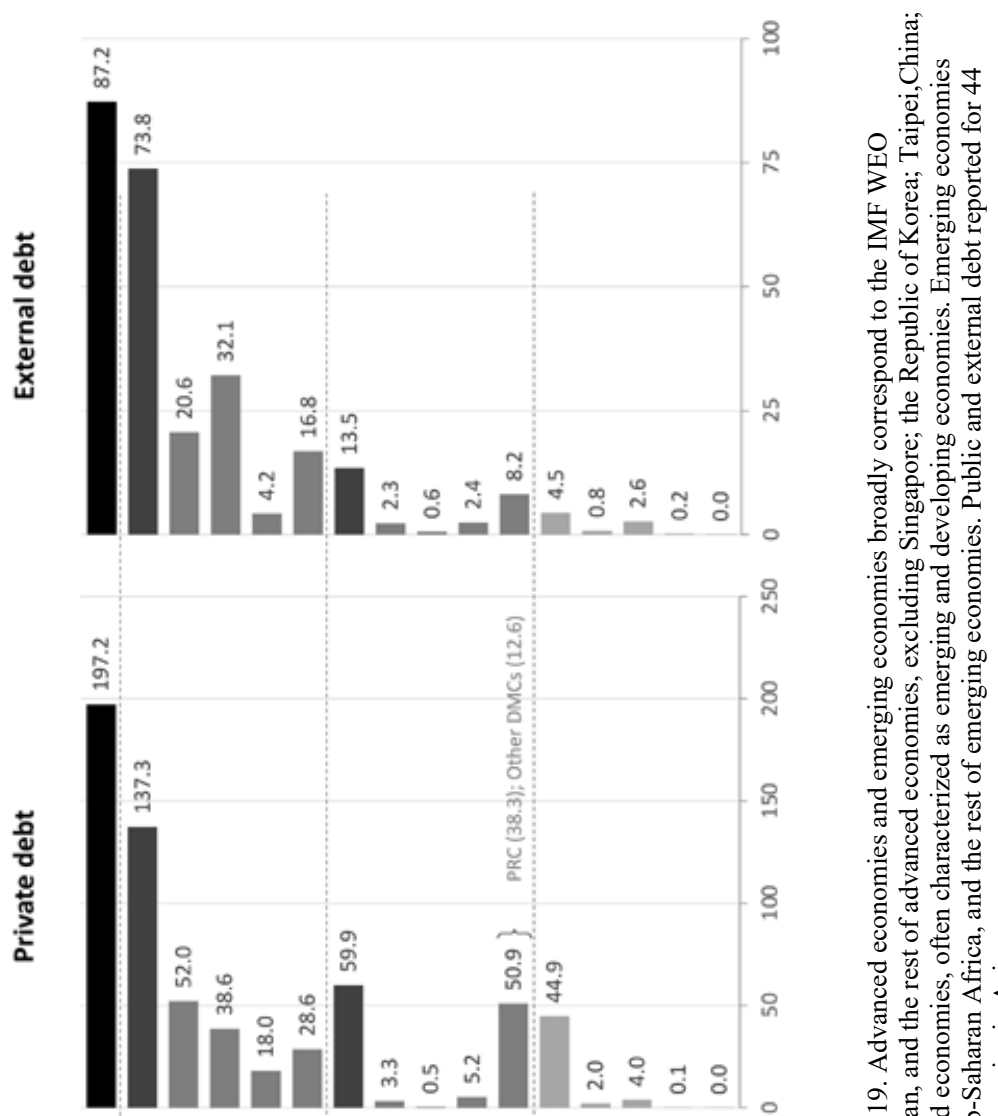

\section{ํㅠ}

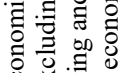

ชु

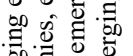

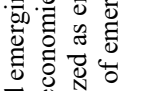

वे

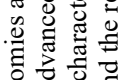

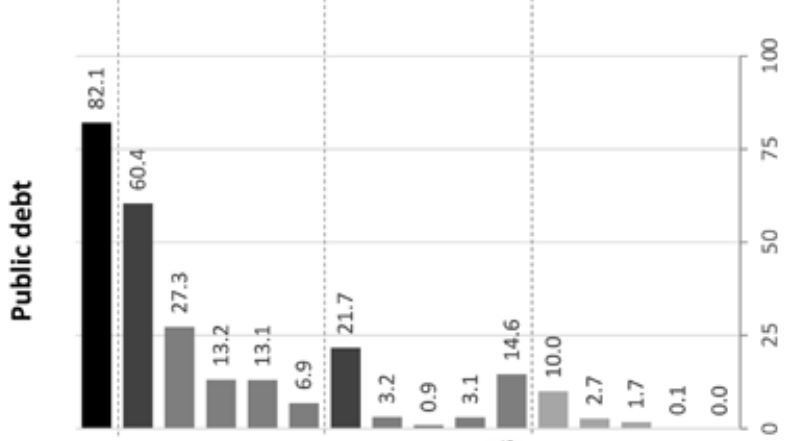

규 है की

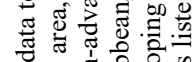

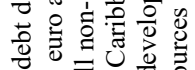

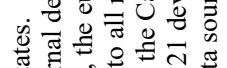

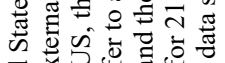

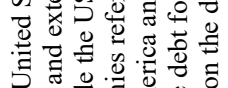
II

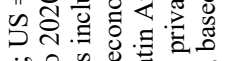

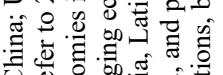

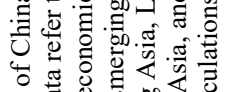

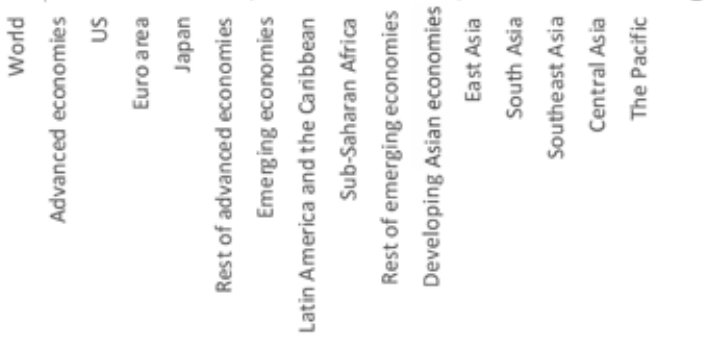

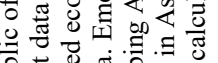

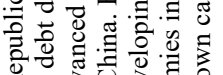

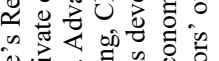

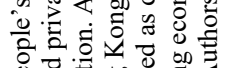

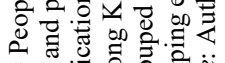

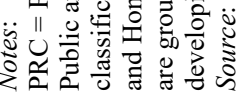



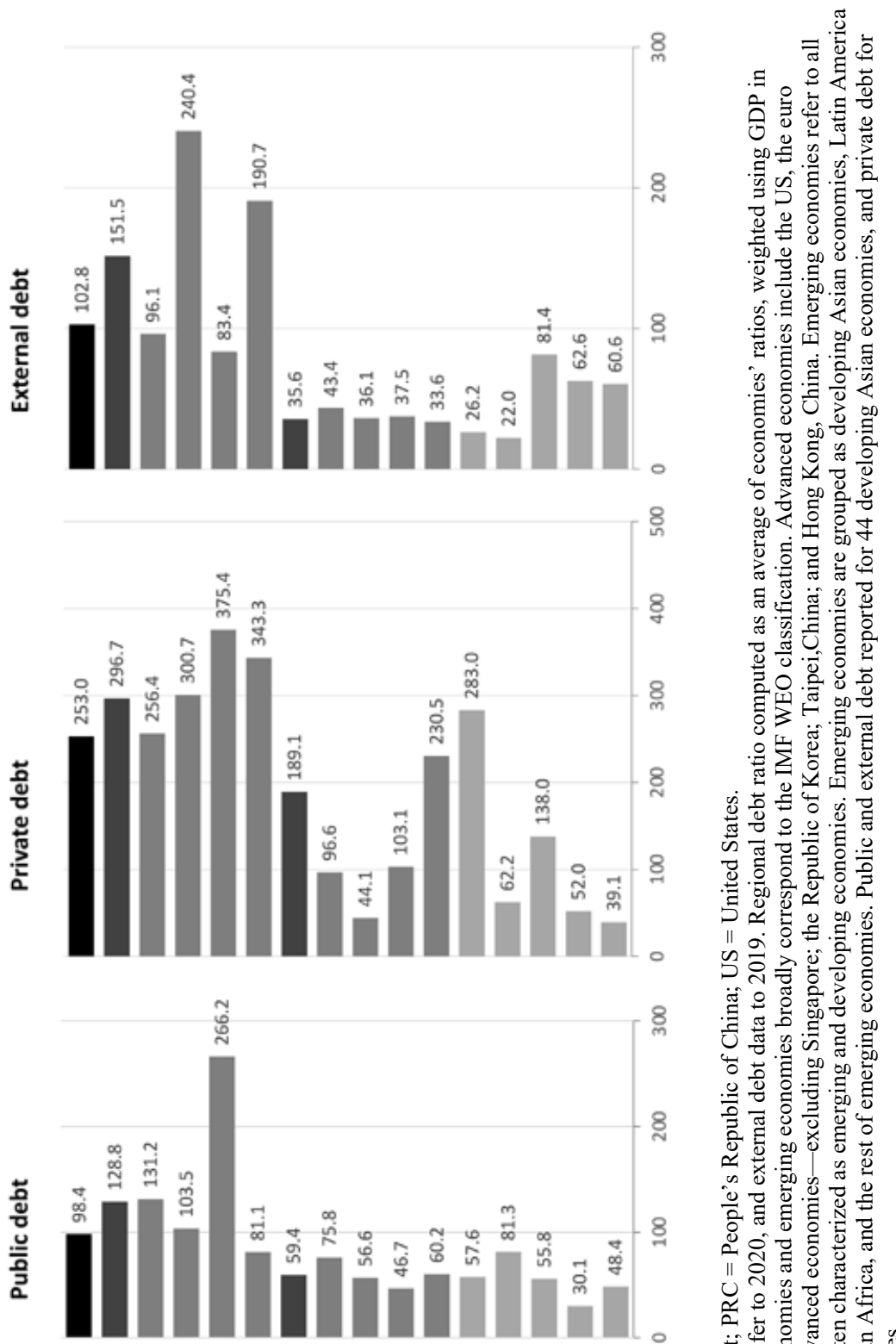

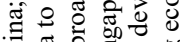

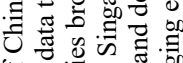

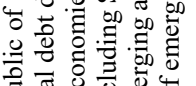

昰言

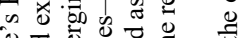

늘

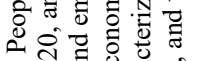

$\|$ ते

ن

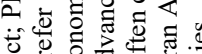

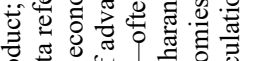

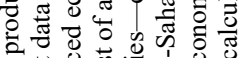

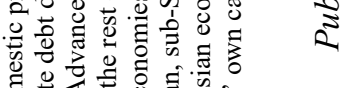

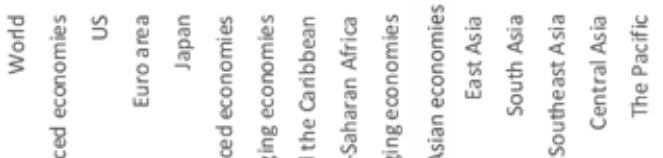

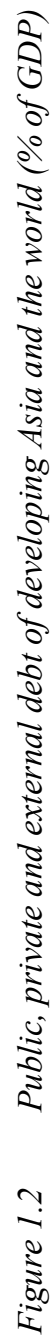




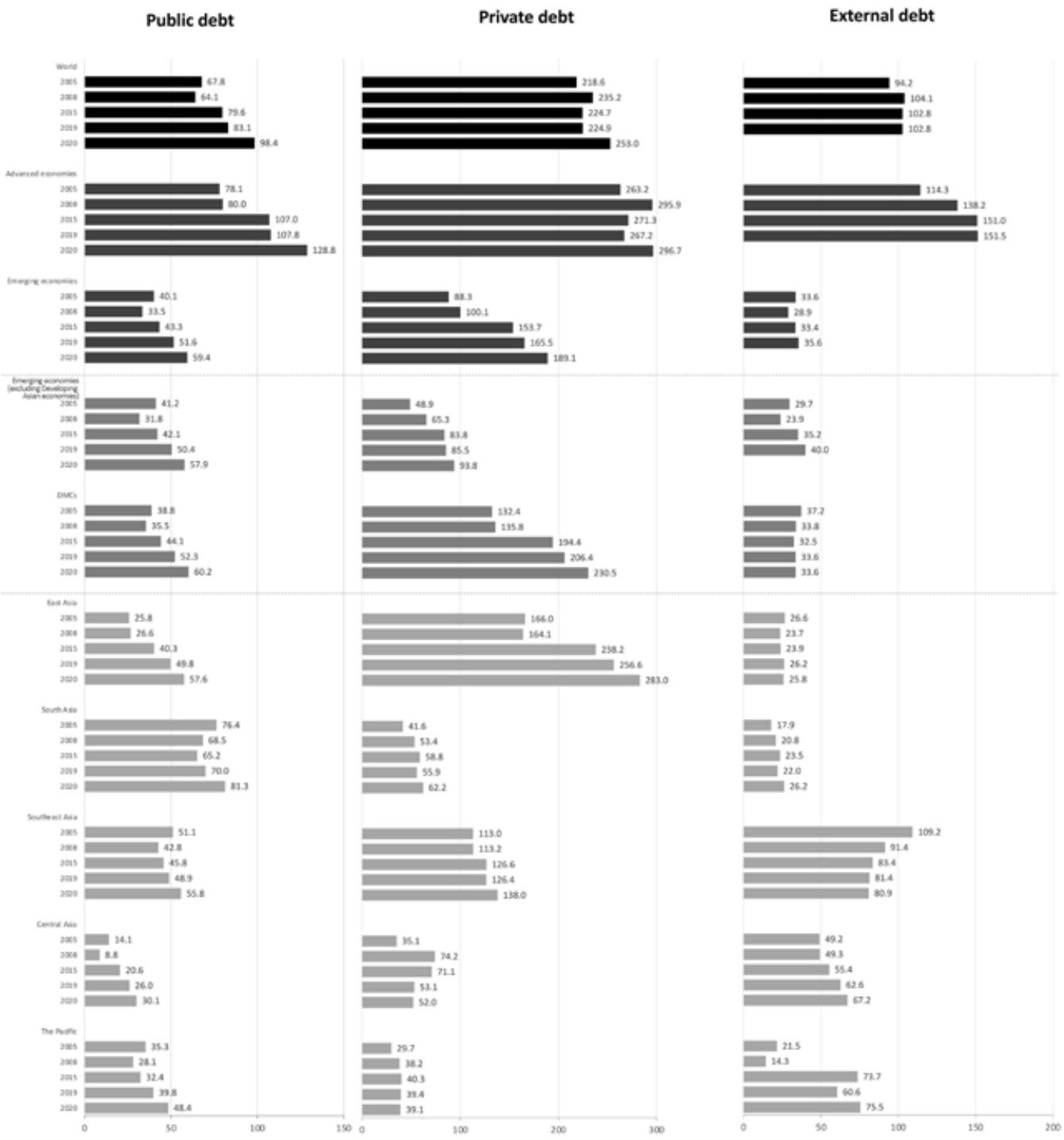

Notes:

GDP $=$ gross domestic product.

Regional debt ratio computed as an average of economies' ratios, weighted using GDP in current dollars. Advanced economies and emerging economies broadly correspond to the IMF WEO classification. Advanced economies exclude Singapore; the Republic of Korea; Taipei,China; and Hong Kong, China. Emerging economies refer to all non-advanced economies - often characterized as emerging and developing economies. Public and external debt reported for 44 developing economies in Asia, and private debt for 21 developing economies in Asia.

Source: Authors' own calculations, based on the data sources listed in endnote 2, as of 14 December 2020.

Figure 1.3 Evolution of public, private, and external debt of developing Asia and the world since the mid-2000s (\% of GDP) 


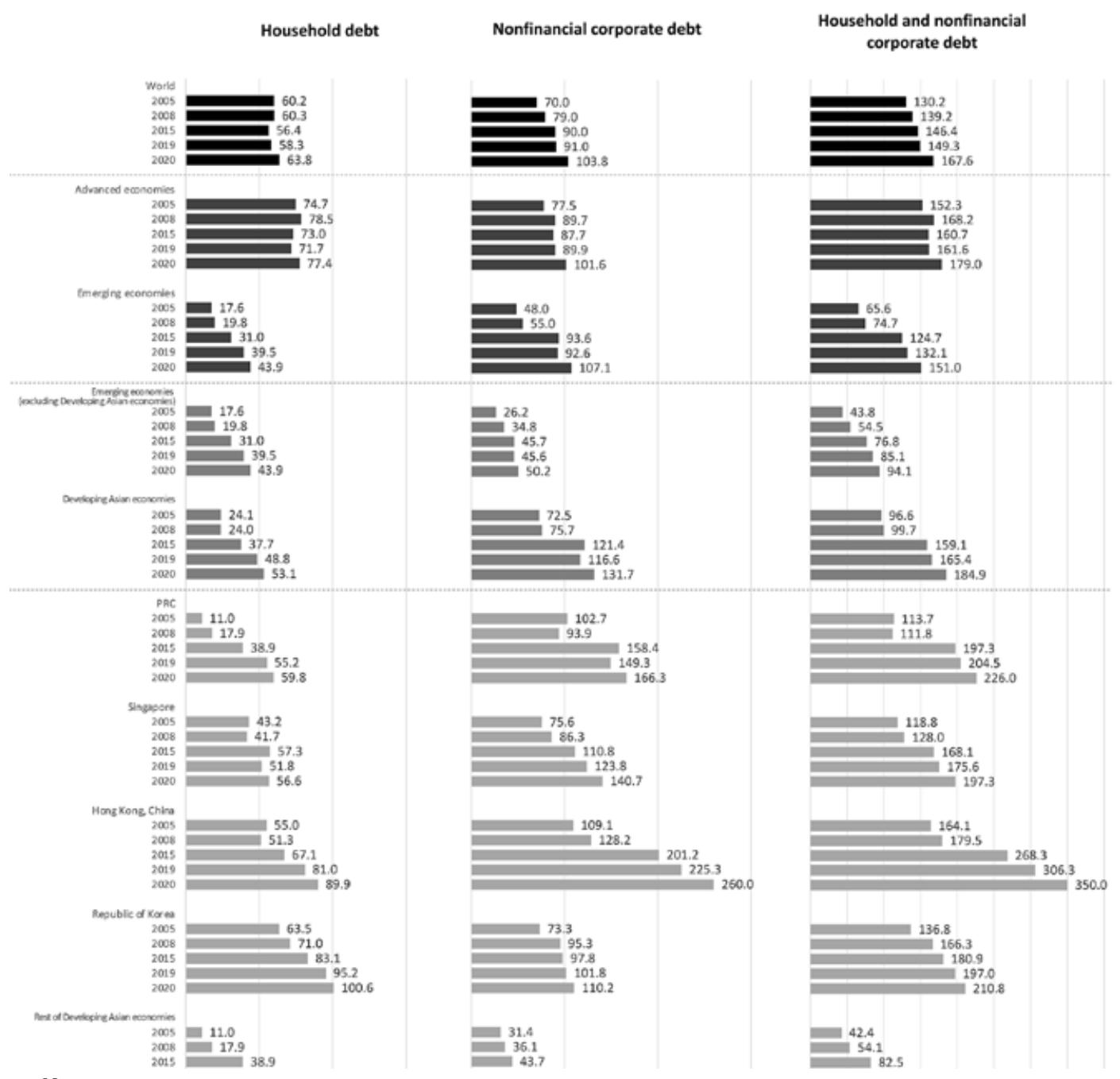

Notes:

$\mathrm{GDP}=$ gross domestic product; $\mathrm{PRC}=$ People's Republic of China.

Regional debt ratio computed as an average of economies' ratios, weighted using GDP in current dollars. Advanced economies and emerging economies broadly correspond to the IMF WEO classification. Advanced economies exclude Singapore; the Republic of Korea; Taipei,China; and Hong Kong, China. Emerging economies refer to all non-advanced economies - often characterized as emerging and developing economies. Private debt reported for 14 developing economies in Asia.

Source: Authors' own calculations, based on the data sources listed in endnote 2, as of 14 December 2020.

Figure 1.4 Evolution of household and nonfinancial corporate debt of developing Asia and the world since the mid-2000s (\% of GDP) 
Table 1.1 Macroeconomic performance of developing Asia, 2007-2019

\begin{tabular}{|c|c|c|c|c|c|c|c|c|c|}
\hline & $\begin{array}{l}\text { Annual } \\
\text { Average }\end{array}$ & $\begin{array}{r}\text { Developing } \\
\text { Asia }\end{array}$ & $\begin{array}{r}\text { South } \\
\text { Asia }\end{array}$ & $\begin{array}{r}\text { Central } \\
\text { Asia }\end{array}$ & $\begin{array}{r}\text { Southeast } \\
\text { Asia }\end{array}$ & $\begin{array}{r}\text { The } \\
\text { Pacific }\end{array}$ & East Asia & PRC & $\begin{array}{r}\text { East Asia } \\
\text { (excluding } \\
\text { the PRC) }\end{array}$ \\
\hline Real GDP & 2007-2011 & 8.0 & 7.3 & 7.0 & 5.3 & 3.9 & 8.9 & 10.7 & 4.0 \\
\hline growth rate & 2012-2015 & 6.3 & 6.4 & 5.1 & 5.1 & 6.5 & 6.6 & 7.5 & 2.8 \\
\hline$(\%)$ & 2016-2019 & 5.8 & 6.2 & 4.0 & 4.9 & 2.9 & 6.0 & 6.7 & 2.6 \\
\hline Fiscal & 2007-2011 & -1.4 & -7.4 & 3.6 & -0.6 & 0.8 & -0.2 & -0.4 & 0.3 \\
\hline balance & $2012-2015$ & -1.8 & -6.8 & 1.3 & -1.0 & -3.6 & -1.0 & -1.2 & 0.0 \\
\hline $\begin{array}{l}\text { (\% of } \\
\text { GDP) }\end{array}$ & 2016-2019 & -3.8 & -6.6 & -0.7 & -1.2 & -2.7 & -3.7 & -4.6 & 1.0 \\
\hline Gross & 2007-2011 & 37.0 & 34.3 & 25.9 & 27.3 & 21.4 & 40.6 & 44.5 & 29.0 \\
\hline capital & $2012-2015$ & 38.3 & 32.3 & 25.6 & 28.8 & 21.1 & 42.0 & 45.2 & 27.5 \\
\hline $\begin{array}{l}\text { formation } \\
(\% \text { of } \\
\text { GDP) }\end{array}$ & 2016-2019 & 37.1 & 29.4 & 26.7 & 28.4 & 20.2 & 40.7 & 43.2 & 27.8 \\
\hline Gross & 2007-2012 & 41.0 & 31.9 & 29.7 & 32.2 & 1.4 & 46.0 & 50.4 & 33.4 \\
\hline national & $2012-2015$ & 40.5 & 30.4 & 27.4 & 31.0 & 13.8 & 45.0 & 47.5 & 34.0 \\
\hline $\begin{array}{l}\text { savings } \\
\text { (\% of } \\
\text { GDP) }\end{array}$ & 2016-2019 & 38.6 & 27.7 & 24.5 & 30.9 & 10.6 & 42.7 & 44.4 & 34.6 \\
\hline Current & 2007-2011 & 4.0 & -2.4 & 4.1 & 5.6 & -9.3 & 5.4 & 5.9 & 4.2 \\
\hline account & 2012-2015 & 2.2 & -1.9 & 1.0 & 2.5 & -5.9 & 3.0 & 2.3 & 6.2 \\
\hline $\begin{array}{l}\text { (\% of } \\
\text { GDP) }\end{array}$ & 2016-2019 & 1.5 & -1.6 & -2.4 & 2.7 & 17.4 & 2.0 & 1.1 & 6.4 \\
\hline
\end{tabular}

Notes:

GDP $=$ gross domestic product; PRC $=$ People's Republic of China.

Developing Asia refers to groups of developing economies in Asia, depending on data availability. Regional figures computed as an average of economies' values, weighted using GDP in current dollars. Real GDP growth rate,

fiscal balance, and current account reported for 44 economies; gross capital formation for 34 economies; and gross national savings for 30 economies.

Source: Authors' own calculations, based on the data sources listed in endnote 2, as of 14 December 2020.

\section{DEBT VULNERABILITIES OF DEVELOPING ASIA}

Developing Asian economies are very heterogeneous in relation to their current levels of public, external and private debt, and their associated vulnerabilities. Key vulnerabilities refer to (1) the current size of debt stocks and gross financing needs - often related to the notions of solvency and liquidity, respectively; (2) the debt structure, which creates exposure to risks (e.g., exchange-rate, interest-rate, and rollover risk); and (3) the debt dynamics, related to both the past trend and prospective outlook for debt stocks. This section explores the debt levels of developing Asia and identifies a number of economies that exhibit debt vulnerabilities in relation to solvency and liquidity. In general terms, developing Asian economies with severe public debt vulnerabilities are concentrated in South Asia, those with elevated private debt are located in East Asia, and economies with significant external debt vulnerabilities are found in Central Asia. 


\subsection{Public Debt}

Public debt vulnerabilities may emerge from the performance of the economy and the government's policies. The government's own repayment capacity and opportunities to smoothly secure borrowed funds, including rollovers, will depend on the actual performance of the economy, as well as on the prospective growth and policy outlook perceived by creditors, investors, and policy makers. Fiscal policies and debt management also matter, and largely impact on vulnerabilities related to solvency, liquidity, and risk exposure. A government's capacity to undertake expansionary fiscal stimulus and fund attendant deficits while preserving sustainable levels of debt is referred to as "fiscal space" (Chapter 10). Alongside, a government's ability to modify the public debt structure and access a variety of sources of financing is referred to as "debt management capacity" (Chapter 14).

Developing Asian economies exhibiting high levels of government debt are vulnerable in relation to their solvency. ${ }^{20}$ The public debt-to-GDP ratio indicates the government's debt burden relative to its repayment capacity, proxied by the size of the economy and measured with the nominal GDP. A public debt ratio above 70 percent signals a level of (solvency-related) debt vulnerability that often calls for stricter monitoring by international organizations, while a ratio below 40 percent indicates a relatively safer level of government liabilities (see Figure 1.5). ${ }^{21} \mathrm{~A}$ few economies exhibit high public debt ratios, signaling solvency-related vulnerabilities. Bhutan, Maldives, Sri Lanka, India, Pakistan, Fiji, the Lao PDR, and Mongolia exhibit public debt ratios above 70 percent, thus being in a vulnerable position in terms of the size of the government debt. Besides, 16 economies have ratios between 40 percent and 70 percent, and 17 economies have ratios below 40 percent. Economies whose public debt ratio is below - although close to - the 70 percent level are the Kyrgyz Republic, Malaysia, the PRC, and Armenia.

Highly indebted developing Asian economies also face significant government gross financing needs (GFN), which make them vulnerable to liquidity risk, with the exception of Bhutan and the Lao PDR. ${ }^{22}$ The government GFN-to-GDP ratio proxies the government's borrowing requirements relative to its repayment capacity. High public debt levels tend to build up significant interest burdens, which constitute an important driver of annual fiscal deficits and attendant government GFN. Concessionality of foreign loans, however, reduces the interest burden as well as rollover risks for any given level of debt. A government GFN ratio above 15 percent signals a level of (liquidity-related) debt vulnerability that also calls for closer monitoring, while a ratio below 10 percent is a relatively safer level of borrowing requirements (see Figure 1.6). ${ }^{23}$ Maldives, Sri Lanka, India, Pakistan, Fiji, and Mongolia face government GFN ratios above 15 percent, and hence both their debt stocks and borrowing-requirement flows are relatively high among developing Asian economies. Thanks to long-term financing of projects with moderate debt-service obligations, the government GFN for Bhutan and the Lao PDR are below 10 percent of GDP. Among those economies whose public debt ratio is below-although close to - the 70 percent level, only the PRC also exhibits a government GFN ratio above 15 percent, while the Kyrgyz Republic, Malaysia, and Armenia face lower GFN. Thailand has a high government GFN despite its moderate public debt ratio. Overall, 8 developing Asian economies have ratios above 15 percent, 6 economies have ratios between 10 percent and 15 percent, and 12 economies have ratios below 10 percent. 

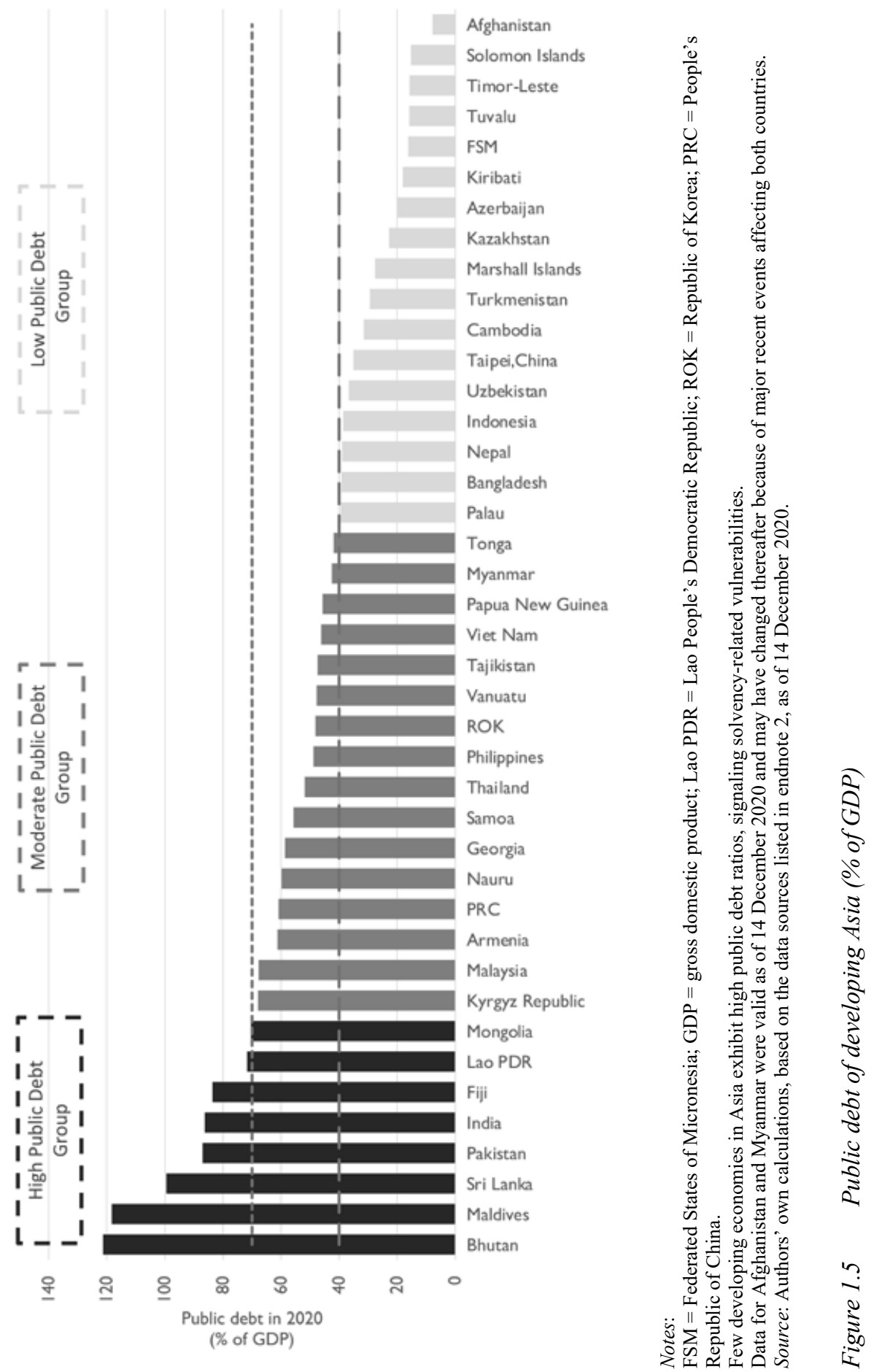


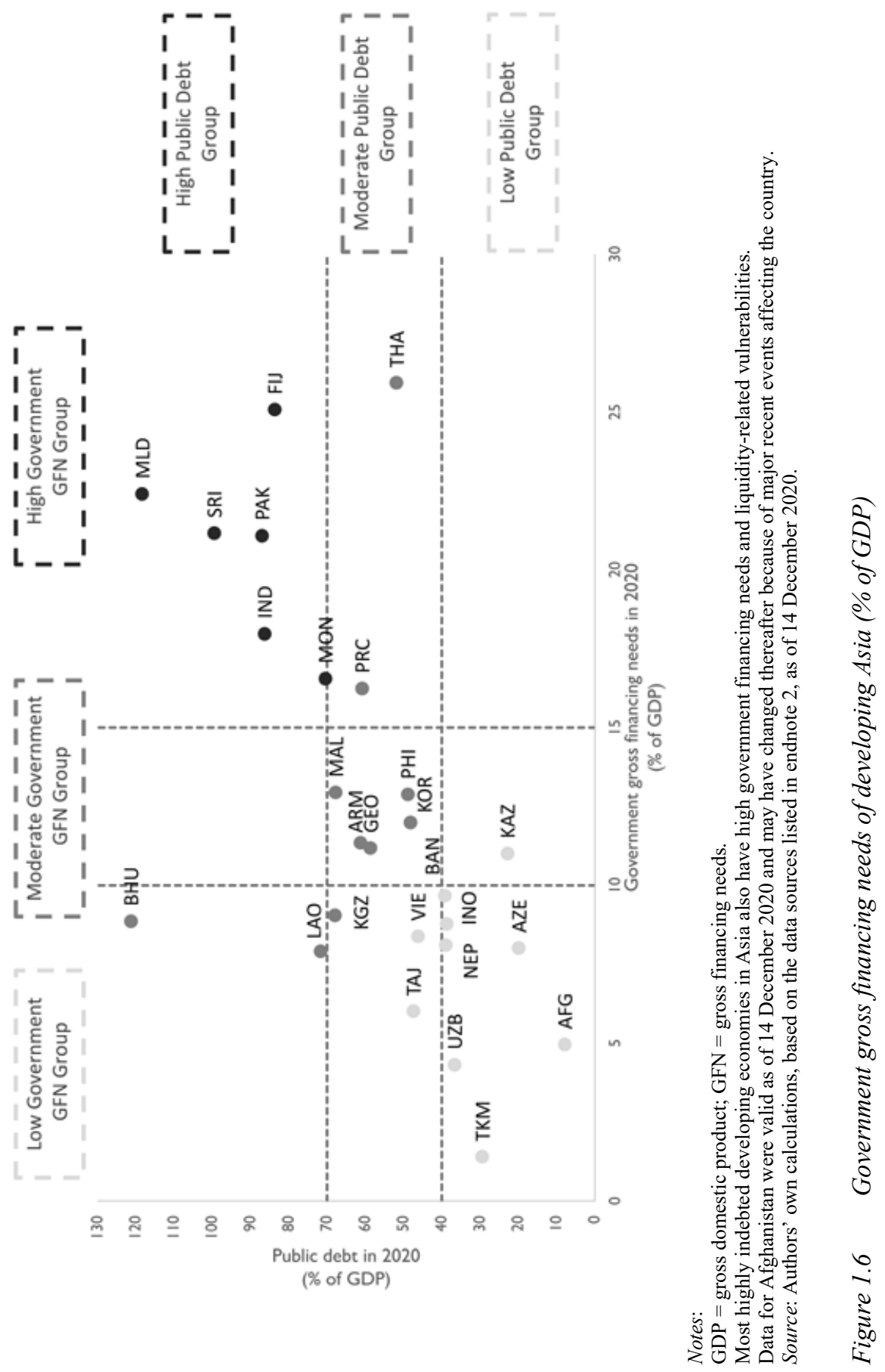


A government's debt management capacity can mitigate, or amplify, the vulnerabilities associated with the public debt. Three groups of developing Asian economies can be identified according to their debt management capacity, as proposed in Chapter 14. In one cluster named Underdeveloped Domestic Government Debt Market group, comprising mainly the Pacific and a few other economies, the governments largely rely on official, external sources of financing and have very limited domestic debt—notably, domestic markets for government debt are underdeveloped and constrain the debt management capacity. In another set named Advanced Domestic Government Debt Market group, which includes long-standing emerging markets like the PRC, India, Malaysia, and Thailand, the governments mainly borrow from domestic sources and have significant domestic debt-notably, local markets for government debt are well developed and widen the debt management capacity. The third cluster, named Developing Domestic Government Debt Market group, includes the remaining economies that lie in-between the other two groups, and whose governments combine different sources of financing - while the domestic market for government debt ranges from nascent to mature.

Highly indebted developing Asian economies do not have strong debt management capacity, except India (Figure 1.7). Bhutan belongs to the Underdeveloped Domestic Government Debt Market group, and its public debt relates to the financing of hydropower projects undertaken in close cooperation with India, a factor that largely mitigates the solvency-related vulnerability suggested by its high level of government debt. India itself is the only case among the highly indebted economies that belongs to the Advanced Domestic Government Debt Market group and thus benefits from wider debt management capacity and access to domestic financing - a factor that mitigates its own solvency-related vulnerability. On the other hand, Maldives, Sri Lanka, Pakistan, Fiji, the Lao PDR, and Mongolia belong to the Developing Domestic Government Debt Market group and have limited debt management capacity and opportunities for domestic borrowing, which does not bode well in view of their vulnerabilities. For economies whose public debt ratio is below-although close to - the 70 percent level, the Kyrgyz Republic and Armenia are included in the Developing Domestic Government Debt Market group, while Malaysia and the PRC are in the Advanced Domestic Government Debt Market group.

\subsection{Private Debt}

A few developing Asian economies have significant levels of private debt, either due to financial centers' leverage (e.g., Singapore and Hong Kong, China) or indebtedness by households (the ROK) or firms (the PRC) (Figure 1.8). ${ }^{24}$ Private-sector liabilities are the highest in Hong Kong, China, where private debt is above 500 percent of GDP; and in Singapore, whose private debt ratio nears 400 percent. Both being important regional financial centers, significant indebtedness by corporations takes place, and is recorded within their jurisdictions disproportionally to their small economic size in terms of output and population. The ROK and the PRC exhibit private debt ratios around 300 percent. Among these economies, households in the ROK are the most indebted, with their liabilities reaching 100 percent of GDP. The PRC's nonfinancial corporations (especially state-owned enterprises) are also highly leveraged, with debts exceeding 150 percent of GDP.

Private debt ratios in developing Asia as a whole grew rapidly from 2007 to 2016, thus building up financial fragility. Household and nonfinancial corporate debts jumped from 100 percent of GDP to nearly 155 percent of GDP in just a decade, and another increase by 15 percentage points 


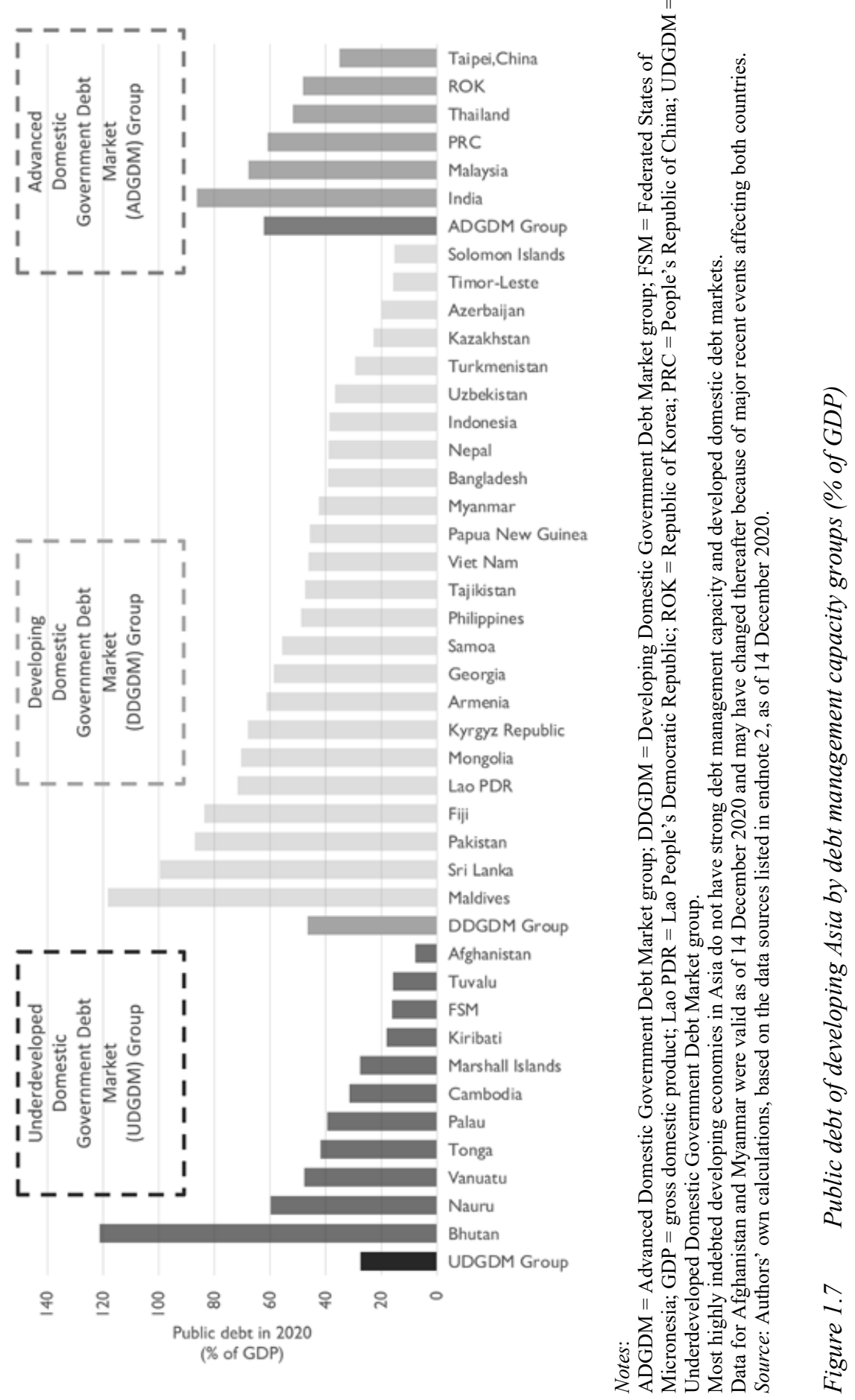



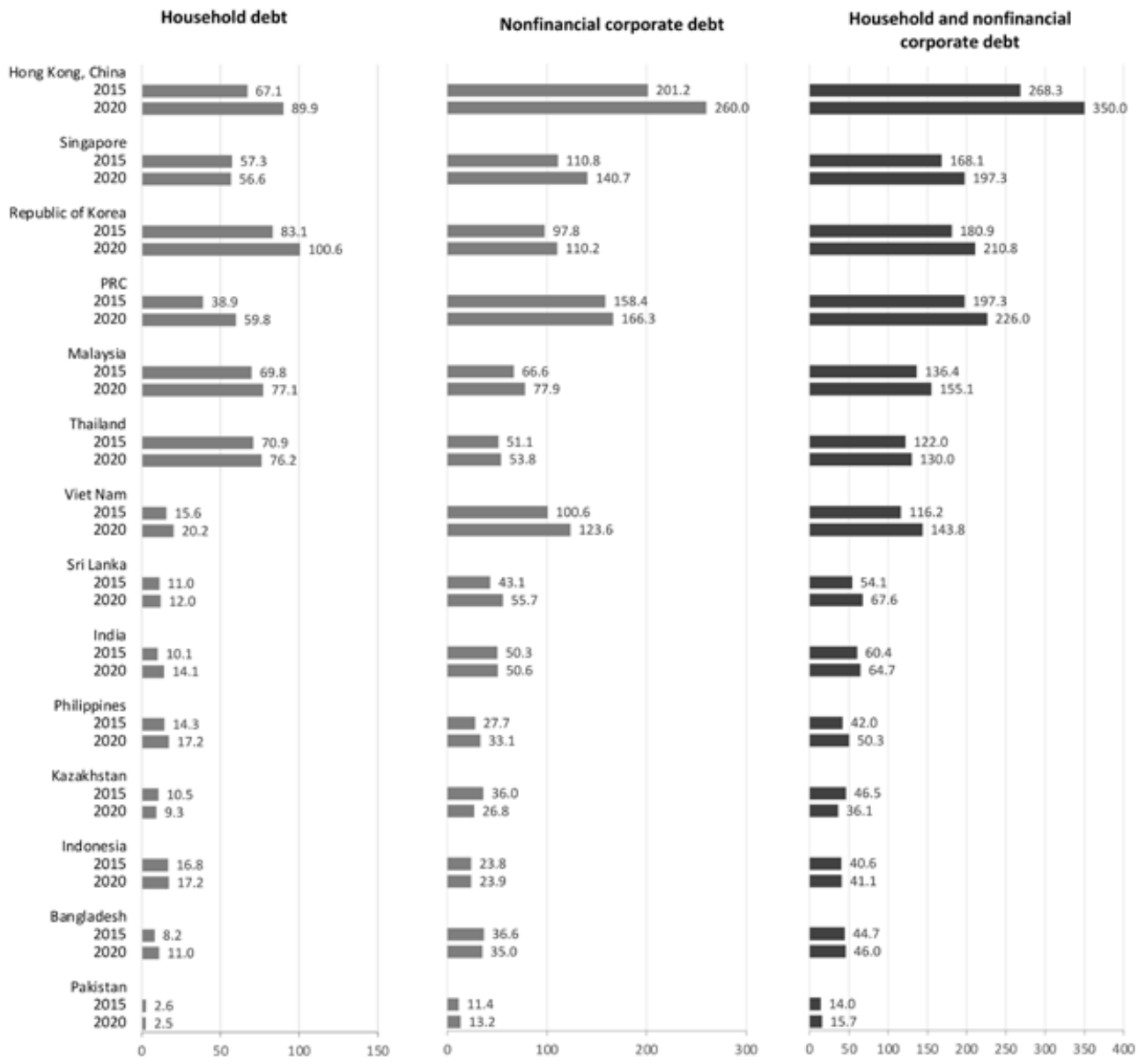

Notes:

GDP $=$ gross domestic product PRC $=$ People's Republic of China.

High private debt ratios observed in regional financial centers, the PRC, and the Republic of Korea.

Source: Authors' own calculations, based on the data sources listed in endnote 2, as of 14 December 2020.

Figure $1.8 \quad$ Private debt of selected developing Asian economies (\% of GDP)

occurred from 2016 to 2020. The private debt ratios of individual economies - like Hong Kong, China; Singapore; and Viet Nam - were still rising before the COVID-19 pandemic unfolded.

A fast-growing private debt ratio is the hallmark of financial fragility - that is, a situation where debtors experience an increase in debt-service obligations relative to their incomes and thus become more dependent on either future income growth, debt refinancing, or both. If income growth slows down, debt refinancing opportunities narrow, or both, private debtors are more likely forced to undertake expenditure adjustments to stay current on their obligations. ${ }^{25}$ Developing Asian economies with high levels of private debt thus face vulnerabilities to the 
extent that their economic growth rates decelerate, the quality of investment deteriorates, and the pool of domestic savings narrows.

\subsection{External Debt}

Developing Asian economies exhibiting high levels of external debt are vulnerable in relation to their economy-wide solvency. ${ }^{26}$ The external debt-to-GDP ratio indicates the debt burden of all residents (including public and private sectors) relative to the economy-wide repayment capacity. An external debt ratio exceeding 70 percent indicates a level of (solvency-related) debt vulnerability relatively high within the group of developing Asian economies, while a ratio below 25 percent implies a safer level of foreign liabilities (Figure 1.9) ${ }^{27}$ External debt ratios surpass 70 percent in Mongolia, Bhutan, the Kyrgyz Republic, Georgia, Armenia, the Lao PDR, Kazakhstan, Papua New Guinea, Tajikistan, Sri Lanka, and Maldives. Besides, 17 economies have ratios between 25 percent and 70 percent, and 12 economies have ratios below 25 percent. The external debt ratio of Cambodia and Malaysia is below-although close to- the 70 percent level.

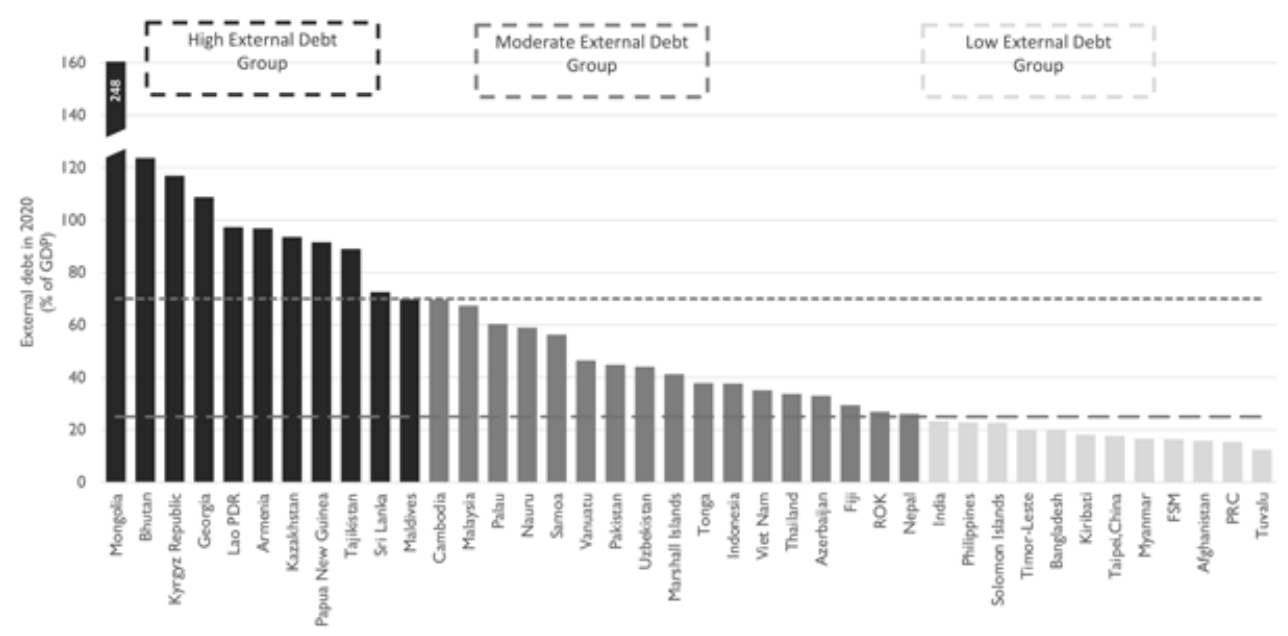

Notes:

FSM $=$ Federated States of Micronesia; GDP = gross domestic product; Lao PDR $=$ Lao People's Democratic Republic; ROK = Republic of Korea; PRC = People's Republic of China.

Few developing economies in Asia exhibit high external debt ratios, signaling solvency-related vulnerabilities.

Data for Afghanistan and Myanmar were valid as of 14 December 2020 and may have changed thereafter because of major recent events affecting both countries.

Source: Authors' own calculations, based on the data sources listed in endnote 2, as of 14 December 2020.

Figure 1.9 External debt of developing Asia (\% of GDP)

Highly indebted developing Asian economies also tend to exhibit large external GFN, which implies vulnerability in relation to their external liquidity — with the exception of the Lao PDR, Sri Lanka, Tajikistan, and Papua New Guinea. ${ }^{28}$ The external GFN-to-GDP ratio proxies the residents' foreign borrowing requirements relative to their repayment capacity. High external 
debt levels build up heavy interest burdens — or similarly, sustained foreign direct investment flows may generate large profit remittances, which constitute an important driver of annual current account deficits and attendant external GFN. An external GFN ratio above 20 percent signals a level of (liquidity-related) debt vulnerability that calls for stricter monitoring, while a ratio below 5 percent indicates a relatively safer level of borrowing requirements (Figure 1.10). ${ }^{29}$ Mongolia, Bhutan, Armenia, Kazakhstan, the Kyrgyz Republic, Georgia, and Maldives have external GFN ratios above 20 percent, and thus both their debt stocks and borrowing-requirement flows imply vulnerabilities. Cambodia is in a similar situation, since its external GFN ratio is close to 20 percent while its external debt ratio nears 70 percent. On the other hand, despite their high level of foreign liabilities, the Lao PDR, Tajikistan, and Sri Lanka maintain moderate external GFN. Given their current account surpluses, Papua New Guinea and Malaysia also face limited external GFN. Overall, 7 economies have ratios above 20 percent, 15 economies have ratios between 5 percent and 20 percent, 9 economies have ratios below 5 percent, and 3 economies have no external GFN.

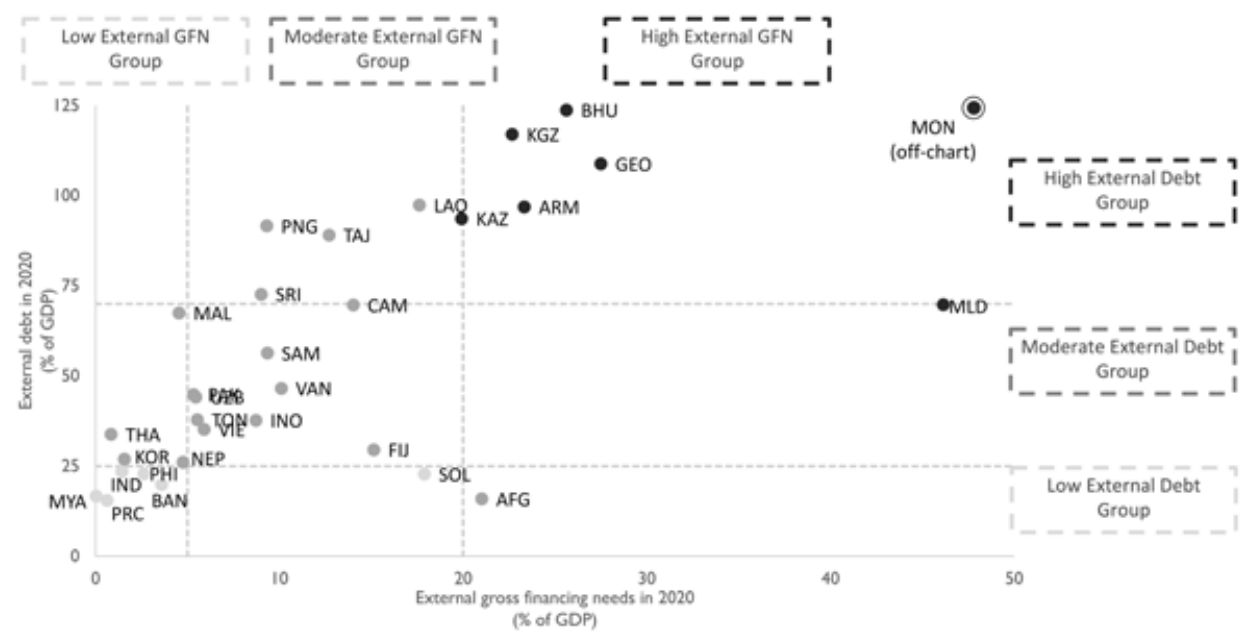

Notes:

$\mathrm{GDP}=$ gross domestic product; GFN = gross financing needs.

Most highly indebted developing economies in Asia also have high external financing needs and liquidity-related vulnerabilities.

Data for Afghanistan and Myanmar were valid as of 14 December 2020 and may have changed thereafter because of major recent events affecting both countries.

Source: Authors' own calculations, based on the data sources listed in endnote 2, as of 14 December 2020.

\section{Figure 1.10 External gross financing needs of developing Asia (\% of GDP)}

Highly indebted developing Asian economies tend to have small international reserve stocks, which heighten their liquidity-related vulnerability. The international reserve stock-to-GDP ratio measures the availability of internationally liquid resources (often in the balance sheet of the Central Bank), relative to the size of the economy. International reserves represent repayment capacity to honor the stock of foreign liabilities, thus mitigating a solvency-related 
vulnerability - as well as a financial reserve that can be utilized to meet the flow of external GFN in the short term, thus alleviating a liquidity-related vulnerability. An international reserve ratio above 25 percent is deemed an adequate level of internationally liquid resources, while a ratio below 25 percent signals a relatively limited availability (Figure 1.11). ${ }^{30}$ Mongolia, Armenia, Kazakhstan, Maldives, the Lao PDR, Tajikistan, Sri Lanka, the Kyrgyz Republic, Georgia, and Papua New Guinea exhibit international reserve ratios below 25 percent, with nominal reserves well below their external debt stocks. Bhutan and Cambodia, instead, hold a significant international reserve position that mitigates the vulnerability associated to their high level of external debt. Malaysia, which also carries a large external debt, eases its own vulnerability through both small external GFN and a robust stock of international reserves.

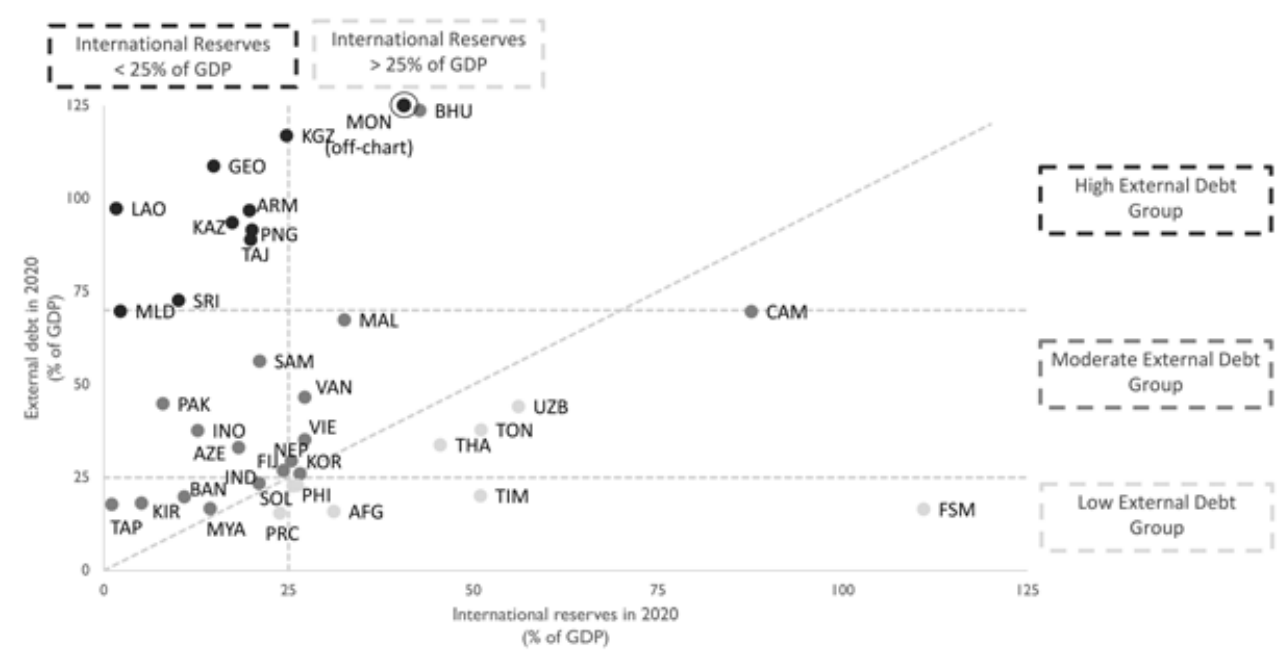

Notes:

$\mathrm{GDP}=$ gross domestic product.

Most highly indebted developing economies in Asia have limited international reserves.

Data for Afghanistan and Myanmar were valid as of 14 December 2020 and may have changed thereafter because of major recent events affecting both countries.

Source: Authors' own calculations, based on the data sources listed in endnote 2, as of 14 December 2020.

Figure 1.11 International reserves of developing Asia (\% of GDP)

\section{THE FISCAL AND DEBT IMPACT OF THE COVID-19 PANDEMIC}

The economic effects of the COVID-19 pandemic caused budget balances and government debt levels to deteriorate worldwide. Developing Asian economies undertook efforts to cope with the health emergency to the extent that their fiscal policy space permitted and the attendant borrowings - jointly with an output contraction, or growth slowdown-increased their public debt burdens to unprecedented levels. This section documents the overall fiscal effort in the Asian developing economies as a whole and the impact on their public debt burden.

Worldwide, the fiscal support to cope with the COVID-19 pandemic in 2020 totaled as much as \$14 trillion - equivalent to about 16 percent of global GDP, according to estimates 

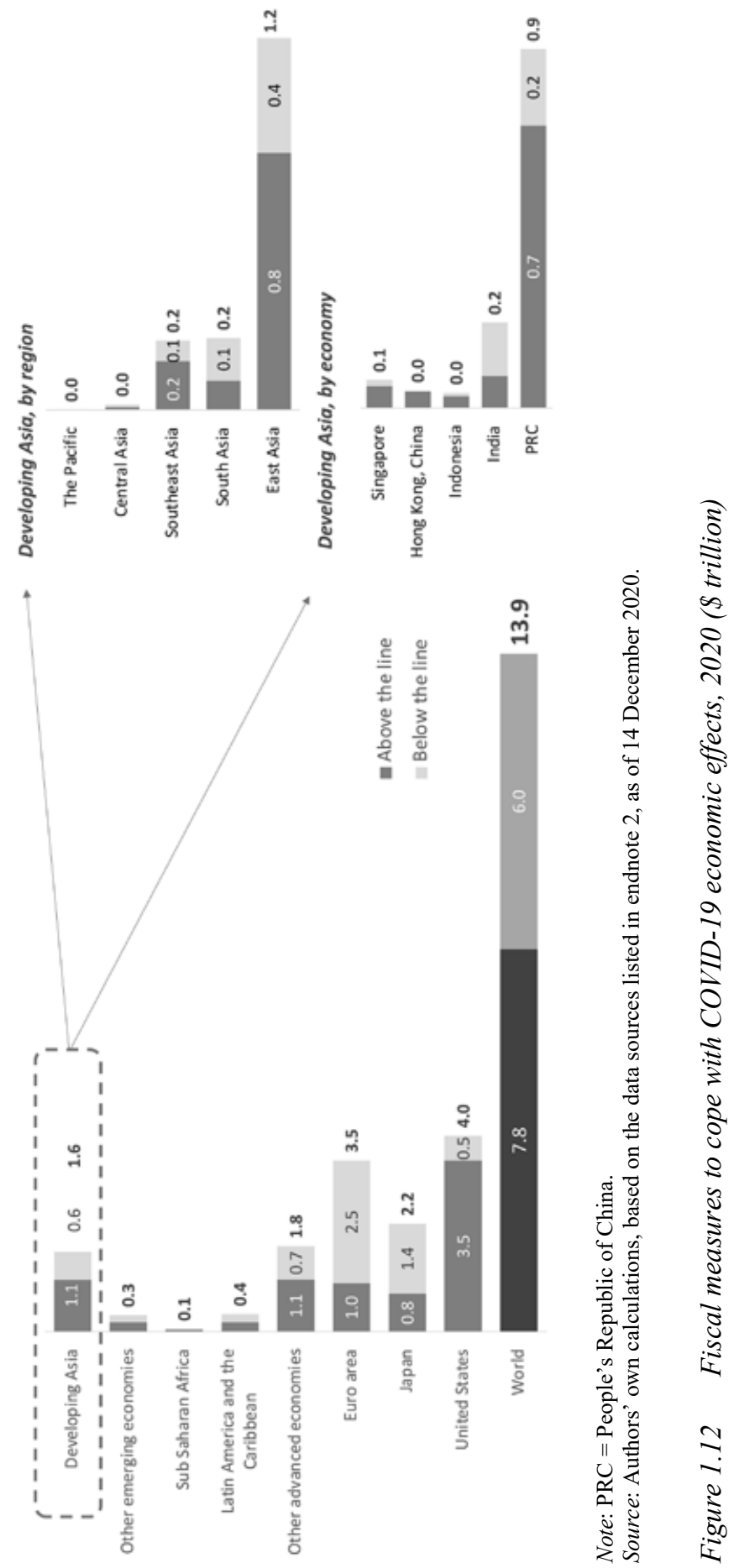
by the IMF (IMF 2021a, 2021b) (Figure 1.12). Within this massive effort, $\$ 8$ trillion corresponded to either higher public spending or forgone revenue (referred to as "above-the-line" fiscal measures), and $\$ 6$ trillion consisting of loans or capital injections ("below-the-line" fiscal measures). ${ }^{31}$ In particular, the developing Asia group jointly undertook a fiscal effort amounting to $\$ 1.6$ trillion, of which $\$ 1.1$ trillion and $\$ 0.5$ trillion implemented, respectively, as above- and below-the-line measures.

Developing Asia undertook different fiscal efforts depending on the direct economic effect of the COVID-19 pandemic and available fiscal space. The PRC, having ample fiscal space, afforded measures to the tune of $\$ 0.9$ trillion, which included spending on epidemic prevention and control, production of medical equipment, unemployment insurance, tax relief, and public investment. India's fiscal effort totaled \$0.2 trillion, involving direct transfers (in-kind and cash), wage support and insurance coverage for workers in the health-care sector, guarantees for a collateral-free lending program, and credit and liquidity provisions. Singapore adopted measures amounting to $\$ 0.1$ trillion to support households with cash payouts, wage subsidies, and job creation.

Due to the economic effects of the COVID-19 pandemic and the fiscal efforts to mitigate them, the dynamic of public debt of developing Asia as a whole expected for 2020-2021 largely breaks from the recent past-which was already building up vulnerabilities, as indicated in section 1. For developing Asia as a whole, public debt is projected to reach an unprecedented level of 64 percent of GDP by 2021, thus jumping up by around 12 percentage points of GDP relative to the pre-pandemic mark in 2019 (Figure 1.13). While economic growth contributed to reduce the public debt ratio by 2.5 percentage points per year (on average) in 2016-2019, its effect would be just 1.8 percentage points in 2020-2021. On the other hand, primary deficits pushed the ratio up by 2.3 percentage points per year before the pandemic, while its impact would be as much as 8.1 percentage points in 2020-2021. As a consequence, the public debt ratio for developing Asia as a whole is expected to increase by 6 percentage points annually (on average) in 2020-2021 - hence, tripling the growth observed back in 2016-2019, which was itself larger than before the global financial crisis. Therefore, the COVID-19 pandemic may leave a legacy of high levels of government debt and heightened solvency-related vulnerabilities for the group of developing Asian economies.

With a few exceptions, developing Asia experienced a heavier debt burden in 2020 relative to the pre-pandemic mark in 2019 (Figure 1.14). A combination of economic contraction (or growth slowdown) and a large fiscal deficit drove the public debt ratios up in 9 out of 10 economies in 2020. The increase in government debt exceeded 30 percentage points of GDP in Maldives and Fiji, both severely hit by the contraction in tourism and international travel, and related fiscal revenues. Fiji actually joined the group of highly indebted economies in 2020, while its public debt burden was moderate before the COVID-19 pandemic. The public debt ratios of Bhutan, India, and Georgia increased by 15 percentage points. On the other hand, only a handful of economies reduced their ratios - the Federated States of Micronesia, Kiribati, Turkmenistan, Nauru, and Tuvalu.

The government debt of developing Asia will continue growing in 2021, although the expected economic recovery would offset the sustained fiscal deficit and thus attenuate the increase in the public debt burden - and even slightly reduce that burden in a few cases (Figure 1.14). Thus, even a quick upturn in 2021 will not cause the higher debt levels reached in the preceding year to return. The COVID-19 pandemic then leaves a common legacy of heavier 
Panel A: 2016-2019

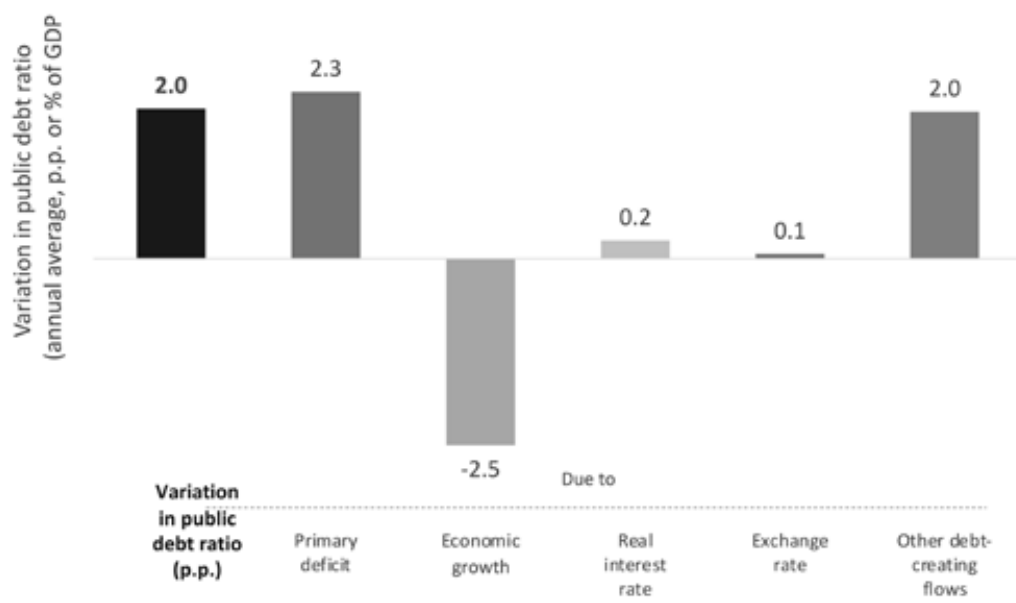

Panel B: 2020-2021

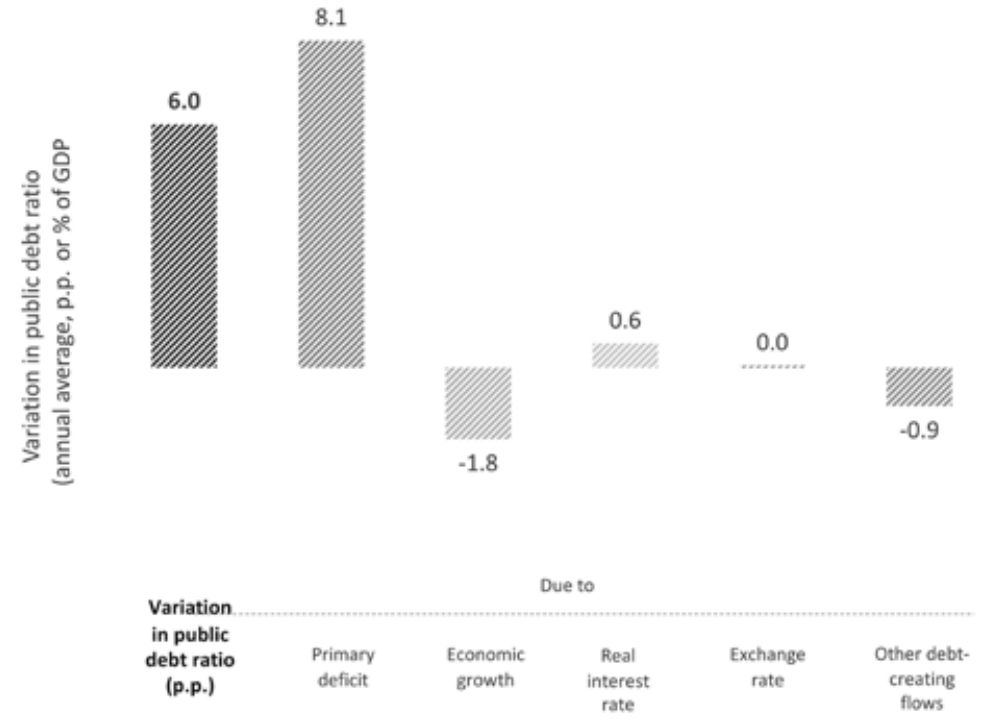

Notes:

GDP = gross domestic product; p.p. = percentage point.

Public debt dynamics of developing Asia accelerated during the COVID-19 pandemic.

Source: Authors' own calculations, based on the data sources listed in endnote 2, as of 14 December 2020.

Figure 1.13 Public debt dynamics of developing Asia during the COVID-19 pandemic 


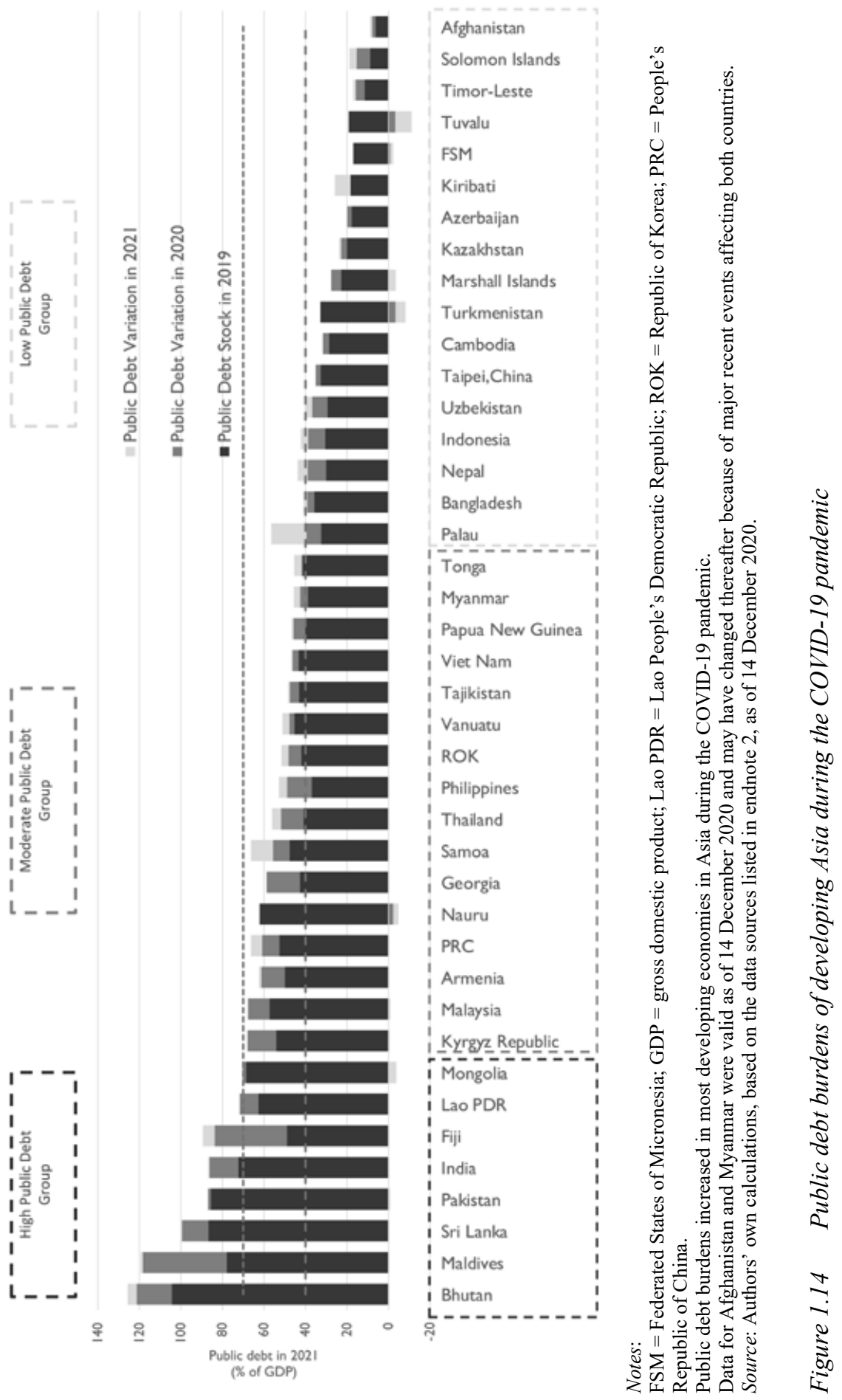


public debt burdens for all individual economies and, as indicated below in section 4, the outlook for the next few years does not suggest any alleviation is to come.

\section{DEBT OUTLOOK IN THE AFTERMATH OF THE COVID-19 PANDEMIC}

While vaccines and preventive measures may eventually resolve the public health crisis triggered by the COVID-19 pandemic, its legacy in terms of public debt will not fade away soon. Furthermore, there is still uncertainty on the path of economic recovery and normalization of fiscal policies adopted in 2020. This section assesses the outlook for public and external debt over the medium term (2021-2024) on the basis of illustrative debt-dynamic simulations. For developing Asia as a whole, the baseline scenario points to an overall stabilization of public and external debt at the levels already observed in 2020. A few developing Asian economies may even see their public debt burdens worsening under such an outlook. Illustrative simulation addressing the risk of a slow recovery, or a failure to normalize fiscal policies, suggest that the public debt ratio of the developing Asia group may near 80 percent of GDP by 2024 .

\subsection{Public Debt}

For most developing Asian economies, the public debt ratios are expected to remain at their current levels in the medium term under the baseline scenario. ${ }^{32}$ Such an outlook contemplates a V-shaped recovery of economic activity in 2021, robust output growth in the medium term (2022-2024), and a gradual normalization of fiscal policy, including phasing out measures taken in 2020 to cope with the COVID-19 pandemic. However, as discussed below, in most economies, significant fiscal deficits will persist over the medium term, and the economic growth will barely offset those imbalances. The weighted average of the public debt ratios of economies - using GDP in current dollars as weights - is projected to grow from 64 percent in 2021 to 71 percent of GDP by 2024 (Figure 1.15). A rising government debt burden in the PRC and the ROK is a major factor driving such dynamics. Instead, the simple average of the public debt ratios of developing Asia stabilizes around 51 percent of GDP in 2021-2024. Public debt stabilization is expected in all regions, except in East Asia.

Overall, developing Asian economies are anticipated to broadly stabilize their levels of public debt in 2021-2024. For a majority of Asian developing economies, the public debt ratio in 2024 will deviate from the 2020 ratio within a range of $+/-10$ percentage points (Figure 1.16). In broad terms, therefore, the outlook for developing Asia reveals a stabilization of public debt burdens over the next few years, at the current levels. A handful of cases will instead exhibit higher public debt ratios and thus heightened (solvency-related) vulnerabilities. For instance, the ratios of the PRC, the ROK, Samoa, and Kiribati are projected to increase by more than 10 percentage points between 2020 and 2024. On the other hand, Bhutan, Pakistan, and Mongolia will achieve lower ratios, with reductions larger than 10 percentage points.

For the group of highly indebted developing Asian economies, the debt vulnerabilities observed in the present will not fade away soon. In most of these economies, the projected fiscal policies in 2021-2024 will widen the budget deficits observed before the COVID-19 pandemic. Mounting deficits will boost the growth of government debt in the medium term (Figure 1.17). ${ }^{33}$ The fiscal deficit ratios of Bhutan, Maldives, Sri Lanka, India, and Fiji are 

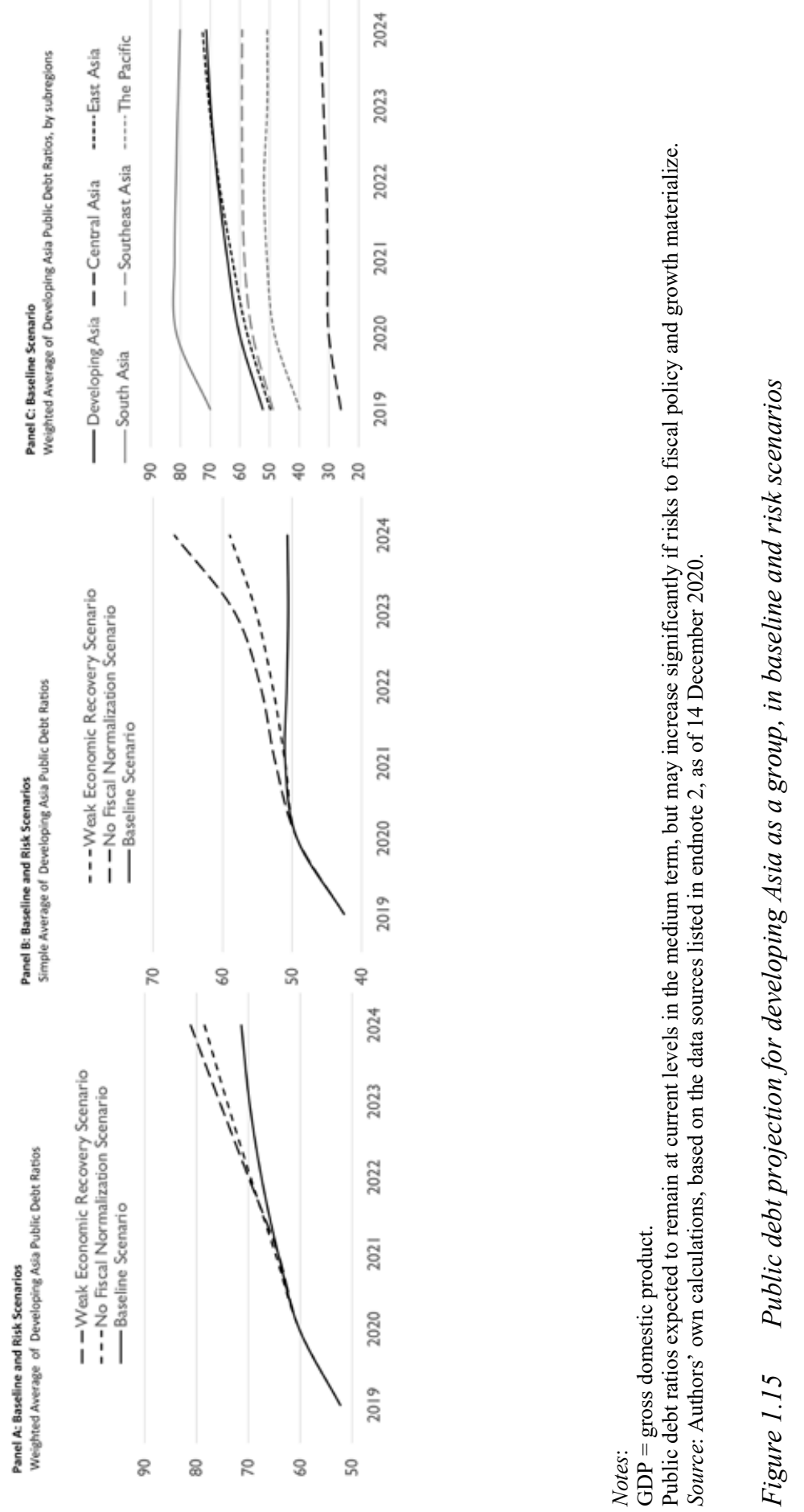


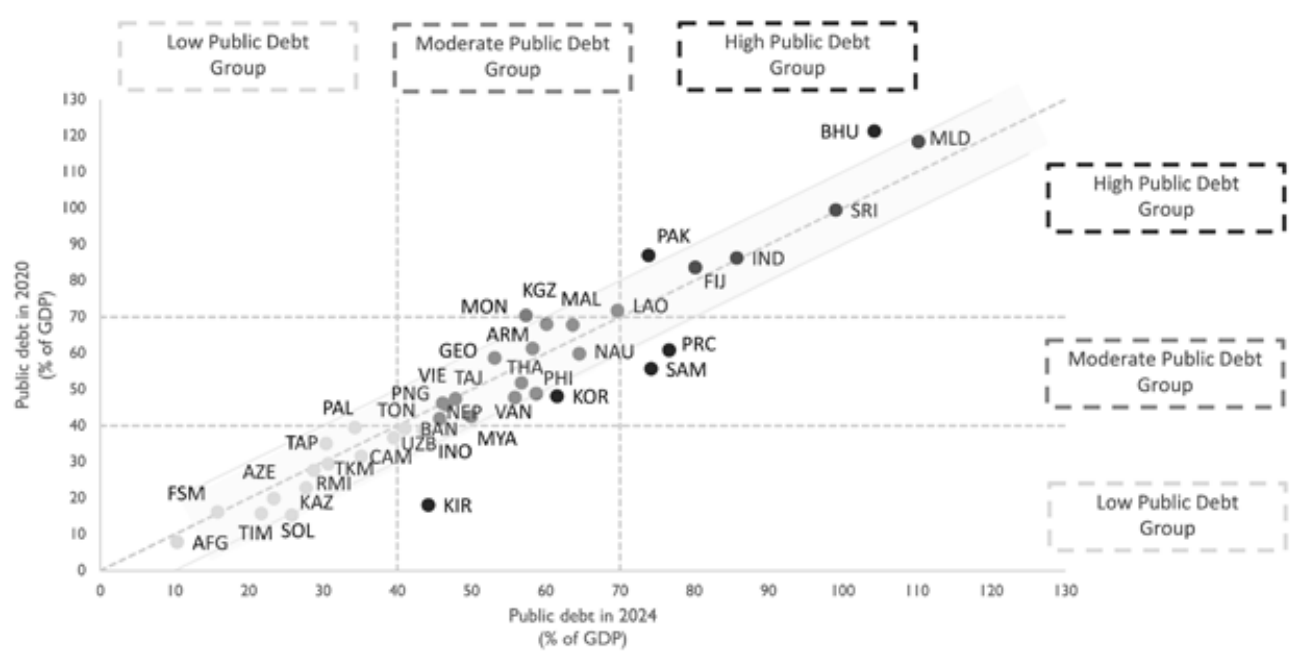

Notes:

$\mathrm{GDP}=$ gross domestic product.

Values within the shaded area deviate by $+/-10$ percentage points of GDP relative to the 45 -degree line. Most developing economies in Asia are expected to broadly stabilize their public debt ratios at current levels in the baseline outlook.

Data for Afghanistan and Myanmar were valid as of 14 December 2020 and may have changed thereafter because of major recent events affecting both countries.

Source: Authors' own calculations, based on the data sources listed in endnote 2, as of 14 December 2020.

\section{Figure 1.16 Public debt projection for developing Asia in baseline scenario, 2020 and 2024 (\% of GDP)}

anticipated to exceed their own historical average observed in 2016-2019. On the other hand, fiscal consolidation efforts are expected to be pursued by Pakistan (ostensibly led by recurrent IMF-supported programs), and, to a lesser extent, also by the Lao PDR. Projected economic growth in 2021-2024 will not be sufficient for highly indebted economies to reduce their public debt ratios below 70 percent by 2024. These economies will not grow out of government debt enough for their (solvency-related) debt vulnerabilities to soften over the next few years (Figure 1.18). The public debt ratios of Bhutan, Maldives, Sri Lanka, India, Pakistan, and Fiji are expected to continue exceeding 70 percent by 2024 , despite significant economic growth helping them to reduce (or stabilize) their public debt burdens relative to 2020. Economic growth will allow Mongolia and the Lao PDR to achieve a moderate public debt ratio by 2024 -although the Lao PDR's debt ratio will remain very close to the 70 percent level.

For the group of developing Asian economies whose public debt ratio is below-although close to - the 70 percent level in 2020, the debt outlook appears stable, with the exception of the PRC. The Kyrgyz Republic, Malaysia, and Armenia are expected to run moderate fiscal deficits and slightly reduce their public debt burden between 2020 and 2024. On the other hand, the PRC's fiscal deficits are projected to reach 10 percent of GDP - far larger than those observed before the COVID-19 pandemic - while the growth slowdown continues. As a result, the PRC government debt may increase from 62 percent of GDP in 2020 to 77 percent by $2024 .{ }^{34}$

Public debt burdens may deteriorate even further if governments fail to normalize fiscal policy, or if the economy fails to recover strongly (see Figure 1.15). Given the uncertainty surrounding the expected outlook, particularly the highly uncertain prospects in the current 


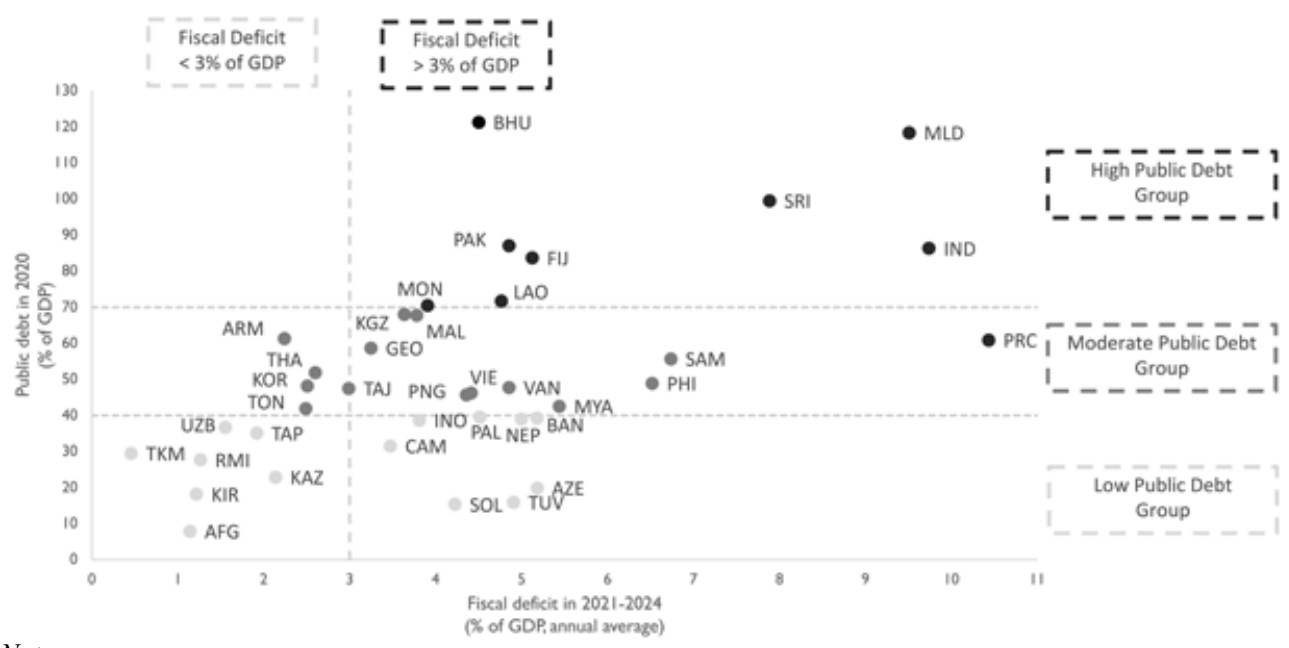

Notes:

$\mathrm{GDP}=$ gross domestic product.

Most highly indebted developing economies in Asia are expected to run large fiscal deficits in 2021-2024.

Data for Afghanistan and Myanmar were valid as of 14 December 2020 and may have changed thereafter because of major recent events affecting both countries.

Source: Authors' own calculations, based on the data sources listed in endnote 2, as of 14 December 2020.

Figure 1.17 General government fiscal deficit projection for developing Asia in baseline scenario, 2021-2024 (\% of GDP)

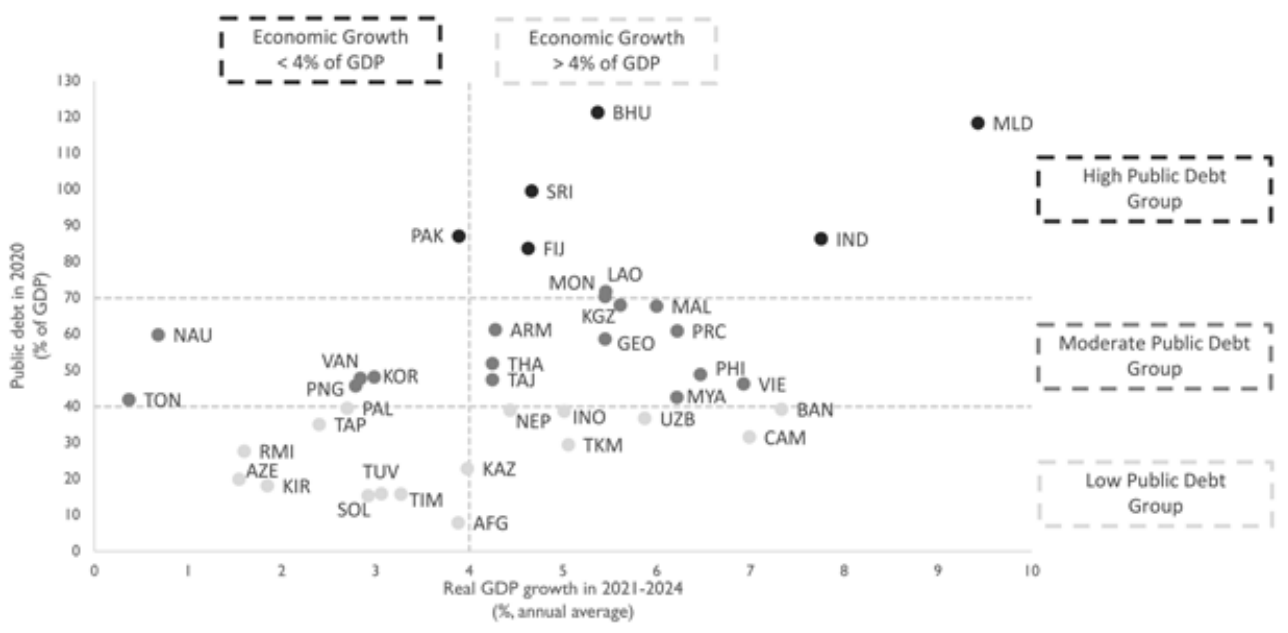

Notes:

GDP $=$ gross domestic product.

Most highly indebted developing economies in Asia will not grow enough in 2021-2024 to reduce their public debt ratios below $70 \%$.

Data for Afghanistan and Myanmar were valid as of 14 December 2020 and may have changed thereafter because of major recent events affecting both countries.

Source: Authors' own calculations, based on the data sources listed in endnote 2, as of 14 December 2020.

Figure 1.18 Economic growth projection for developing Asia in baseline scenario, 2021-2024 (real GDP growth rate, \%) 
juncture of the COVID-19 pandemic, two alternative scenarios are formulated to assess risks. One risk scenario contemplates a failure (or political impossibility) to normalize fiscal policy and phase out the measures adopted in 2020. It then assumes that the fiscal deficit-to-GDP ratio remains at the 2020 level all throughout the 2021-2024 period. The other risk scenario envisages a weak economic recovery, possibly caused by a deterioration of long-term growth potential in the aftermath of the COVID-19 pandemic. Economic growth rates in 2022-2024 are then assumed to be half those foreseen in the baseline scenario. In both risk scenarios, the weighted average of the public debt ratio of developing Asia reaches nearly 80 percent of GDP by 2024 , while the simple average exceeds 60 percent of GDP. In all cases, the projected ratios rise by 10 percentage points (or more) over and above the baseline outlook.

Highly indebted developing Asian economies are particularly sensitive to the risks to fiscal policy and economic recovery (Figure 1.19). If the fiscal policy is not normalized in Pakistan, or if growth falters in Bhutan and Mongolia, their public debt ratios in 2024 will be similar to those observed in 2020 - not lower, as expected under the baseline outlook. Failure to normalize fiscal policy could push the ratios of Maldives and Fiji up by more than 40 percentage points above their current levels. Similarly, a weak economic recovery could push the ratios of Sri Lanka, India, and the Lao PDR up by more than 10 percentage points above their current levels. In both risk scenarios, the public debt burdens of the Kyrgyz Republic, Malaysia, and Armenia exceed 70 percent of GDP in 2024, while the PRC's surpasses 80 percent.

\subsection{External Debt}

Foreign liabilities of the developing Asia group are also expected to remain stable in the medium term under the baseline outlook. The weighted average of the external debt ratio of developing Asia using GDP in current dollars as weights is projected to remain around 20 percent between 2021 and 2024, while the simple average stabilizes at 56 percent in the same period. All regions either stabilize, or slightly reduce, their external debt ratios in the medium term. Central Asia, in particular, will reduce its foreign liabilities but still carry a heavy external debt burden.

Similar to public debt, most developing Asian economies are anticipated to stabilize their external debt ratios in 2021-2024. For several Asian developing economies that have reliable data apt for making projections, the external debt ratio in 2024 will deviate from the 2020 ratio within a range of $+/-10$ percentage points (Figure 1.20). ${ }^{35}$ Overall, the outlook for developing Asia indicates a stabilization of external debt burdens in the medium term - at the levels currently observed. However, rising foreign liabilities are expected in some cases, for example, the external debt ratio of Maldives and Cambodia is projected to increase by around 20 percentage points between 2020 and 2024. On the other hand, Kazakhstan and Malaysia will achieve lower ratios, with reductions larger than 20 percentage points.

External debt burdens may also worsen if the economy fails to recover strongly, and a handful of developing Asian economies with significant foreign liabilities will be particularly affected (Figure 1.21). For instance, Bhutan, Maldives, the Lao PDR, and Cambodia are expected to increase their external debt ratios by more than 25 percentage points relative to the current levels. 


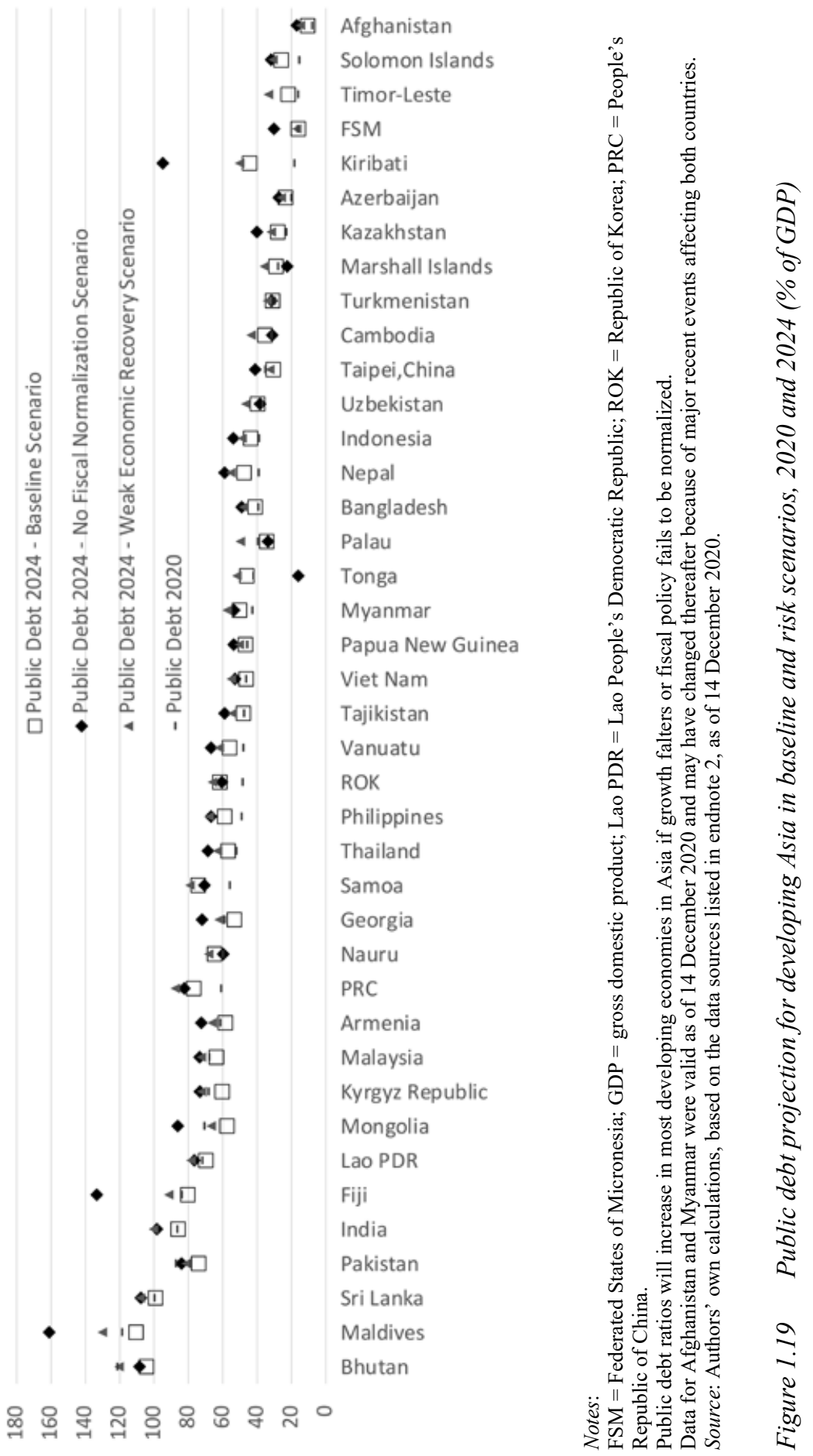




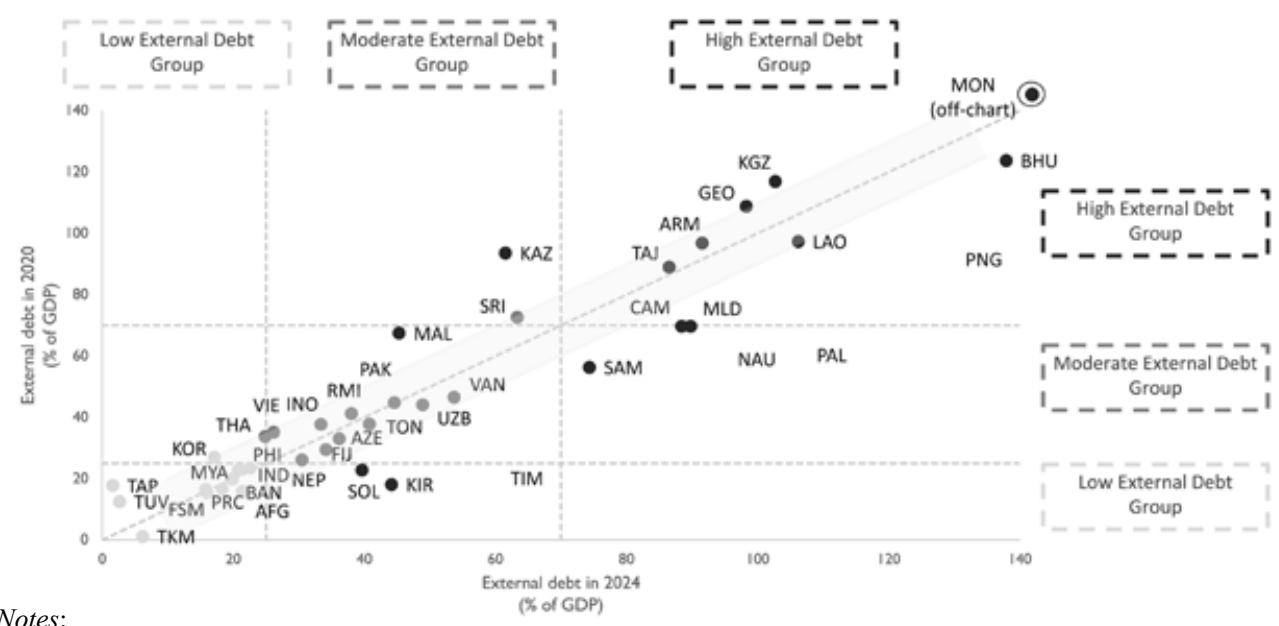

Notes:

GDP $=$ gross domestic product.

Values within the shaded area deviate by $+/-10$ percentage points of GDP relative to the 45 -degree line. Most developing economies in Asia are expected to broadly stabilize their external debt ratios at current levels in the baseline outlook. Data for Afghanistan and Myanmar were valid as of 14 December 2020 and may have changed thereafter because of major recent events affecting both countries.

Source: Authors' own calculations, based on the data sources listed in endnote 2, as of 14 December 2020.

Figure 1.20 External debt projection for developing Asia in baseline scenario, 2020 and 2024 (\% of GDP)

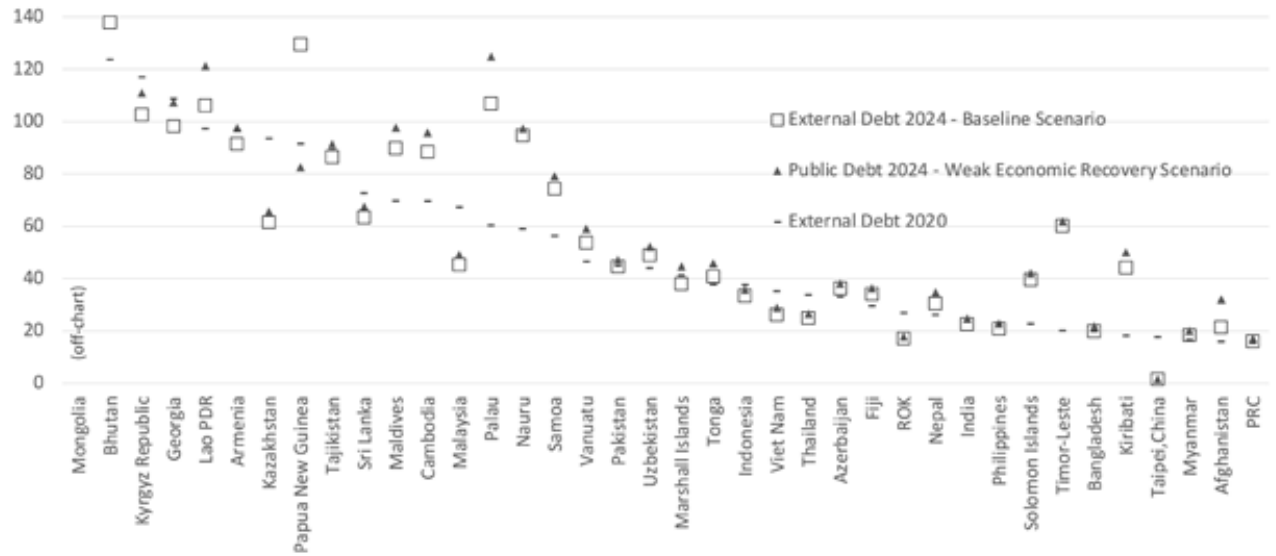

Notes:

$\mathrm{FSM}=$ Federated States of Micronesia; GDP $=$ gross domestic product; Lao PDR = Lao People's Democratic

Republic; ROK = Republic of Korea; PRC = People's Republic of China.

External debt ratios of developing economies in Asia will increase in most economies if growth falters.

Data for Afghanistan and Myanmar were valid as of 14 December 2020 and may have changed thereafter because of major recent events affecting both countries.

Source: Authors' own calculations, based on the data sources listed in endnote 2, as of 14 December 2020.

Figure 1.21 External debt projection for developing Asia in baseline and risk scenarios, 2020 and 2024 (\% of GDP) 


\section{NOTES}

1. The views expressed therein are those of the authors and do not necessarily reflect the views and policies of ADB, its Board of Governors or the governments they represent.

2. Data sources for the empirical analysis in this chapter include the IMF's Global Debt Database (https://www.imf.org/external/datamapper/datasets/GDD) and World Economic Outlook (WEO) datasets (https://www.imf.org/en/Publications/WEO), especially for fiscal forecast assumptions; the ADB's Asian Development Outlook (ADO) (https://www.adb.org/publications/series/asian -development-outlook); the World Bank Group's World Development Indicators (WDI) (https:// datatopics.worldbank.org/world-development-indicators) and Debt Reporting System Database (DRS) (https://data.worldbank.org/products/ids); and the Institute of International Finance Debt Database (IIFDD) (https://www.iif.com/Research/Capital-Flows-and-Debt/Global-Debt-Monitor).

3. Ferrarini et al. (2012) and Ferrarini and Ramayandi (2015) describe ADB's earlier analysis on public debt sustainability in Asia.

4. IMF's WEO (https://www.imf.org/en/Publications/WEO) and IIFDD (https://www.iif.com/ Research/Capital-Flows-and-Debt/Global-Debt-Monitor).

5. The contribution of developing Asia to global output rises to 38 percent when GDP in purchasing power parity dollars is used instead, thus adjusting for differences in domestic prices across economies.

6. Chapter 12 discusses energy-related public indebtedness in Pakistan and Sri Lanka.

7. Ferrarini and Ramayandi (2012) analyzed empirically the fiscal policy undertaken by selected developing Asian economies from the late 1990s to the global financial crisis, and found evidence consistent with the hypothesis that governments adjust budget balances in response to increasing public debt levels - that is, as if fiscal reaction functions were in place.

8. The ongoing structural transformation and rebalancing of the PRC economy largely accounts for the regional growth slowdown. The PRC currently generates at least half of the total output produced by Asian developing economies. In 2020, it accounted for nearly 60 percent of developing Asia output when using GDP in current dollars, or about 50 percent, if utilizing GDP in purchasing power parity dollars. Growth deceleration in the PRC economy is transmitted to other regions through, inter alia, supply chains (e.g., East Asia and Southeast Asia) and commodity prices (e.g., Central Asia).

9. Notably, while the advanced economies' public debt ratio jumped from 73 percent in 2007 to 108 percent by 2013 as result of policy responses to the global financial crisis, it remained fairly stable until 2019, with fiscal deficits reduced. In contrast, the public debt ratio of developing Asia was fairly stable between 2007 and 2013, and then it increased by nearly 10 percentage points of GDP until 2019, with fiscal deficits growing. Other emerging economies also experienced a broadly stable public debt ratio from 2017 to 2013, and a rising one afterwards.

10. Public debt has increased in several developing Asian economies even before the COVID-19 pandemic: 16 economies exhibited public debt ratios exceeding 50 percent in 2019, compared with only 9 back in 2007.

11. IIFDD compiles private debt data mainly from advanced economies, emerging markets, and middle-income economies; thus, many developing Asian economies are not included.

12. State-owned enterprises play an important role in private leveraging. According to IIFDD data on firms listed on domestic stock exchanges, those classified as state-owned, based on equity ownership, account for a large share of nonfinancial corporate debt, notably in the PRC ( 85 percent), Malaysia ( 80 percent), and India (55 percent).

13. The PRC generated 35 percent of the $\$ 100$ trillion flow of new public debt issued globally between 2005 and 2020.

14. In stark contrast, the world's private debt ratio was broadly stable around 225 percent throughout the same period, while the ratios of major countries like the US even declined.

15. Policy reforms adopted by the PRC since 2015 contributed to slowing down the nonfinancial corporate indebtedness. Some reforms actually substituted public debt for private debt: for example, the debt swap converting off-budget liabilities owed by the special purpose vehicles (often created by local governments for undertaking and financing infrastructure investments) into on-budget government debt; and the establishment of a bond market for subnational borrowing to mitigate off-budget 
fiscal activity (Chapter 6). In addition, between 2016 and 2019, general government fiscal deficit in the PRC averaged 4.6 percent of GDP per year, far higher than the deficit recorded from 2007 to 2015 (Table 1.1).

16. The investment rates in developing Asia remain high and broadly stable, but the national gross savings rates are declining overall, notably in the PRC, following the rebalancing toward consumption (Table 1.1). To the extent that households and firms rely on domestic financing, a narrowing pool of savings may constrain their borrowing opportunities. Fueled by domestic savings, the demand for financial assets is analyzed by Chapter 13 in the context of aging populations in Asia.

17. Singapore and Hong Kong, China represent only 3 percent of the regional GDP but owe nearly 40 percent of the external debt of developing Asia as a whole.

18. The development of domestic government debt markets in developing Asia and the expansion of local-currency public debt have been regularly monitored and analyzed in ADB's Asian Bonds Online at AsianBondsOnline. https://asianbondsonline.adb.org/.

19. Sustained, large current account surpluses were instrumental to external deleveraging and international reserve accumulation in developing Asia. Since the aftermath of the global financial crisis, however, the buildup of reserves slowed down markedly, driven by the contraction in external surpluses (Table 1.1.) and a few episodes of financial turmoil where central banks intervened to stabilize foreign exchange markets (e.g., the taper tantrum in 2013 or the PRC sell-off in 2015).

20. From a theoretical perspective, solvency refers to a government's capacity to repay its outstanding financial obligations over an extended period of time, in view of an intertemporal balance between its revenues and expenditures under the current fiscal policies. A creditworthy government is deemed able to generate sufficient budgetary resources to afford debt-service obligations over the medium- to long term, without having to borrow systematically in order to roll over maturing liabilities and pay interests. It is also expected to generate those budgetary resources broadly as a result of its current fiscal policies without having to undertake major policy adjustments that are politically, economically or socially untenable, or to restructure current or future financial obligations, or to outright default on them. In practice, a nonexplosive dynamic of the public debt-to-GDP ratio signals a balanced evolution of financial obligations and repayment capacity (including both budgetary resources and access to rollovers). For a discussion on the notion of solvency and sustainability from the perspective of practitioners in international organizations, see IMF $(2017,2021 \mathrm{a})$ and Debrun et al. (2019).

21. Public debt at the end of 2020 refers to the general government and is an estimate from the ASDM based on the Asian Development Outlook December 2020 growth and inflation forecasts (ADB 2020) and the WEO October 2020 fiscal forecasts (IMF, 2020). The IMF's Market-Access Country Debt Sustainability Analysis (MAC DSA) uses the 70 percent value as a benchmark for debt vulnerabilities of emerging markets, and 85 percent for advanced economies (IMF 2013, 2021a). The 40 percent value is established based on percentiles within the group of developing Asian economies. Singapore; Hong Kong, China; and Brunei Darussalam are excluded from the classification because their public debts do not play a major role in deficit financing. Niue and the Cook Islands are excluded due to lack of reliable data.

22. Conceptually, liquidity refers to a government's capacity to borrow funds in the short term, at a reasonable cost, in order to meet its Gross Financing Needs (GFN) (e.g., fiscal deficit, amortization payments, and other debt-creating transactions). A government with access to liquidity is deemed able to issue debt in the short term to secure borrowed resources and fund fiscal deficits and debt-service obligations fully or to a significant extent, without facing higher-than-normal interest rates (inclusive of risk premia) or severe disruptions in the financing flows provided by regular creditors and investors holding public debt (i.e., low rollover risk). In practice, a low (or moderate) level of government GFN, measured relative to nominal GDP or fiscal revenue, is an indication that sufficient liquidity may be accessed at a reasonable cost. In theory, a solvent debtor would always be liquid because creditors would recognize the short-term borrowing sought by the former is part of a long-term path where their financial liabilities and repayment capacity are balanced. Thus, creditors would see no heightened risk in extending new financing, engaging in debt rollovers, or maintaining their exposure to public debt and associated risks. In practice, however, problems with creditors' coordination or information may arise, including deep uncertainty about a debtor's 
resources or capacity to undertake policy adjustments. In this context, a government debtor who is essentially solvent may fail to secure sufficient liquid resources at a reasonable cost from its creditors, and eventually fail to repay maturing debts or suffer an unbearable interest burden, thus becoming an insolvent debtor. For a discussion on the relation between liquidity and sustainability, see IMF (2017, 2021a) and Debrun et al. (2019).

23. Government GFN in 2020 is an estimate from the ASDM based on the ADO December 2020 growth and inflation forecasts (ADB 2020), the WEO October 2020 fiscal forecasts (IMF 2020), and the World Bank DRS government debt data. GFN are computed as the sum of fiscal deficit in 2020 plus the central government's debt outstanding at the end of 2019 whose residual maturity is 12 months or less. The IMF's MAC DSA uses the 15 percent value as a benchmark for debt vulnerabilities of emerging markets, and 20 percent for advanced economies (IMF 2013, 2021a). The 10 percent value is established based on percentiles within the group of developing Asian economies. Singapore; Hong Kong, China; and Brunei Darussalam are excluded from the classification, for reasons explained elsewhere, as well as several economies in the Pacific; Taipei,China; and Cambodia - due to lack of reliable data.

24. Private debt in 2020 is sourced from the IIFDD (which contains information for 14 economies: Bangladesh; Hong Kong, China; India; Indonesia; Kazakhstan; Malaysia; Pakistan; the Philippines; the PRC; the ROK; Singapore; Sri Lanka; Thailand; and Viet Nam) and the IMF Global Debt Database (which reports data for another 7 developing Asian economies: Afghanistan, Myanmar, Nepal, Samoa, Solomon Islands, Tajikistan, and Vanuatu). Private debt comprises households, nonfinancial corporations, and financial corporations. There are no established thresholds to signal vulnerabilities concerning private debt.

25. A protracted period of increasing financial fragility builds systemic liquidity and solvency risks, which ultimately can undermine the sustainability of private debt.

26. From a theoretical perspective, external solvency refers to the capacity of all residents of a given economy to repay their outstanding foreign liabilities over an extended period of time, in view of an intertemporal balance between exports and imports under the current macroeconomic policies. Similar to public-sector solvency, external creditworthiness rules out systematic rollovers of maturing external debt, restructuring or defaults, as well as major policy adjustments to correct external imbalances. In practice, a nonexplosive dynamic of the external debt-to-GDP ratio (or a ratio relative to exports) signals economy-wide solvency. See IMF (2021a) and Manasse and Roubini (2005).

27. External debt at the end of 2020 is an estimate from the ASDM based on the ADO December 2020 growth and inflation forecasts (ADB 2020), the WEO October 2020 foreign trade forecasts (IMF 2020), and the World Bank WDI external debt data. The 70 percent and 25 percent values are chosen based on percentiles of the empirical distribution of external debt within developing Asia as a group. There are no institutionalized thresholds for foreign liabilities akin to those in the IMF's MAC DSA concerning public debt. Singapore and Hong Kong, China are excluded from the classification in view of their role as financial centers. Brunei Darussalam, Niue, the Cook Islands, and Turkmenistan are excluded due to lack of reliable data.

28. Conceptually, external liquidity refers to the ability of all residents of a given economy to borrow from abroad in the short term, at a reasonable cost, in order to meet their GFN (e.g., current account deficit and amortization payments, net of financing flows such as foreign direct investment or use of international reserves). Similar to public-sector liquidity, external liquidity rules out adverse conditions for rollover maturing liabilities and securing new foreign financing. In practice, a low (or moderate) level of external GFN - measured relative to nominal GDP or exports - is an indication that sufficient liquidity may be accessed at a reasonable cost. See IMF $(2013,2021 \mathrm{a})$.

29. External GFN in 2020 is an estimate from the ASDM based on the ADO December 2020 growth and inflation forecasts (ADB 2020), the WEO October 2020 foreign trade forecasts (IMF 2020), and the DRS external debt data. External GFN are computed as the sum of current account deficit in 2020 plus external debt outstanding at the end of 2019 whose residual maturity is 12 months or less. The IMF's MAC DSA uses the 20 percent value as a benchmark for debt vulnerabilities of emerging markets, and 35 percent for advanced economies (IMF 2013, 2021a). The 5 percent value is established based on percentiles within developing Asia as a group. The classification excludes financial centers, Turkmenistan, a few economies in the Pacific for which reliable data are not available, and 
economies with no external GFN, that is, whose current account surplus exceeded the amortizations of foreign liabilities.

30. International reserves in 2020 are an estimate from the ASDM based on the ADO December 2020 growth and inflation forecasts (ADB 2020), the WEO October 2020 foreign trade forecasts (IMF 2020), and the World Bank WDI international reserve data. The 25 percent value is chosen based on percentiles of the empirical distribution of international reserves across developing Asia. There are no institutionalized thresholds for foreign assets. Developing Asian economies for which the external debt ratio was not reported are also excluded from the analysis in the main text.

31. "Above-the-line" measures include additional spending in the health sector (such as health-care equipment or testing facilities) and protective aid to vulnerable groups (e.g., in-kind and cash transfers, wage support to poor households). "Below-the-line" measures refer to equity infusions, subsidized lending, and capital injections to state-owned enterprises and private businesses.

32. The baseline scenario includes projections from 2021 to 2024 reported in the ASDM based on the ADO December 2020 growth and inflation forecasts (ADB 2020), the WEO October 2020 growth (IMF 2020), fiscal and foreign trade forecasts, and the World Bank WDI and DRS external debt data. A few developing economies are excluded from the scenario analysis: Brunei Darussalam; the Cook Islands; Hong Kong, China; Niue; and Singapore; and only from the risk scenarios, Tonga and Vanuatu.

33. An average annual fiscal deficit of 3 percent in 2021-2024 is used as a benchmark to assess developing Asia. Fiscal deficit forecasts are from the WEO October 2020 (IMF 2020). In addition, an average annual growth rate of real GDP of 4 percent in 2021-2024 is used as a benchmark, which is close to the unweighted regional average. Growth forecasts are from the ASDM based on the ADO December 2020 (ADB 2020) and the WEO October 2020 (IMF 2020).

34. Vulnerabilities from household and nonfinancial corporate debts may intensify in developing Asian economies like the PRC, which are undergoing a slowdown in prospective economic growth relative to historical trends. Financial fragility built up before the COVID-19 pandemic may heighten in the PRC, where private debt is high, and the prospects of growth deceleration more likely.

35. External debt ratios are not calculated for Brunei Darussalam; Hong Kong, China; Singapore; Turkmenistan; and several economies in the Pacific. For a detailed analysis of indebtedness in developing economies in the Pacific, see Chapter 5. 


\section{REFERENCES}

Asian Development Bank (ADB). 2020. Asian Development Outlook (ADO) 2020: What Drives Innovation in Asia?. Manila.

Debrun, X., J. Ostry, T. Willems and C. Wyplosz. 2019. Debt Sustainability. In S. Ali Abbas, A. Pienkowski and K. Rogoff (eds), Sovereign Debt: A Guide for Economists and Practitioners. Oxford: International Monetary Fund and Oxford University Press.

Ferrarini, B. and A. Ramayandi. 2012. Public Debt Sustainability Assessments for Developing Asia. In B. Ferrarini, J. Raghbendra and A. Ramayandi. Public Debt Sustainability in Developing Asia. Manila: ADB.

Ferrarini, B. and A. Ramayandi. 2015. Public Debt Sustainability in Developing Asia: An Update. $A D B$ Economics Working Paper Series. No. 468. Manila: ADB.

Ferrarini, B., J. Raghbendra and A. Ramayandi. 2012. Public Debt Sustainability in Developing Asia. Manila: ADB.

International Monetary Fund (IMF). 2013. Staff Guidance Note for Public Debt Sustainability Analysis in Market-Access Countries. Washington, DC.

International Monetary Fund (IMF). 2017. Review of the Debt Sustainability Framework in Low-Income Countries: Proposed Reforms. IMF Policy Paper. Washington, DC.

International Monetary Fund (IMF). 2020. World Economic Outlook, October 2020: A Long and Difficult Ascent. Washington, DC.

International Monetary Fund (IMF). 2021a. Review of the Debt Sustainability Framework for Market Access Countries. IMF Policy Paper. No. 2021/003. Washington, DC.

International Monetary Fund (IMF). 2021b. Government Support is Vital as Countries Race to Vaccinate. Fiscal Monitor Update, January 2021. Washington, DC. Accessed at: https://www.imf.org/ en/Publications/FM/Issues/2021/01/20/fiscal-monitor-update-january-2021.

Manasse, P. and N. Roubini. 2005. "Rules of Thumb" for Sovereign Debt Crises. International Monetary Fund Working Paper. No. 05/42. Washington, DC: IMF. 